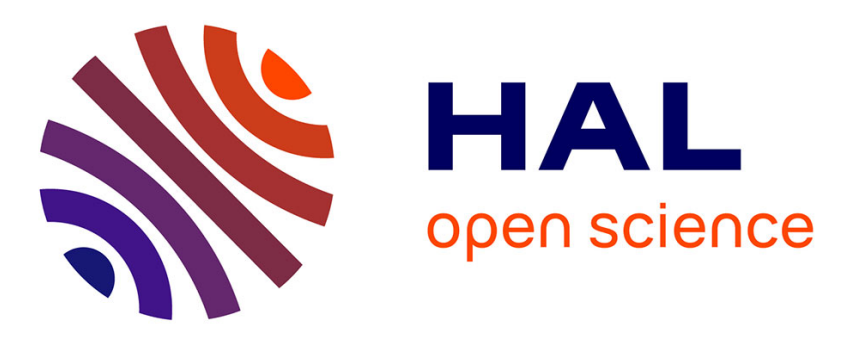

\title{
Colloidal Control on the Distribution of Rare Earth Elements in Shallow Groundwaters
}

Olivier Pourret, Gérard Gruau, Aline N. Dia, Mélanie Davranche, Jérôme Molenat

\section{- To cite this version:}

Olivier Pourret, Gérard Gruau, Aline N. Dia, Mélanie Davranche, Jérôme Molenat. Colloidal Control on the Distribution of Rare Earth Elements in Shallow Groundwaters. Aquatic Geochemistry, 2010, 16 (1), pp.31-59. 10.1007/s10498-009-9069-0 . insu-00562460

\section{HAL Id: insu-00562460 \\ https://hal-insu.archives-ouvertes.fr/insu-00562460}

Submitted on 16 Oct 2012

HAL is a multi-disciplinary open access archive for the deposit and dissemination of scientific research documents, whether they are published or not. The documents may come from teaching and research institutions in France or abroad, or from public or private research centers.
L'archive ouverte pluridisciplinaire HAL, est destinée au dépôt et à la diffusion de documents scientifiques de niveau recherche, publiés ou non, émanant des établissements d'enseignement et de recherche français ou étrangers, des laboratoires publics ou privés. 
Pourret Olivier, Gruau Gérard, Dia Aline, Davranche Mélanie, and Molénat Jérome. (2010) Colloidal control on the distribution of rare earth elements in shallow groundwaters. Aquatic Geochemistry 16 (1), 31-59.

This document is the author's final manuscript version of the journal article, incorporating any revisions agreed during the peer review process. Some differences between this and the publisher's version remain. You are advised to consult the publisher's version if you wish to cite from this article.

www.springerlink.com 


\section{COLLOIDAL CONTROL ON THE DISTRIBUTION OF RARE EARTH ELEMENTS IN SHALLOW GROUNDWATERS}

Olivier Pourret $^{1,2, \S}$, Gérard Gruau, ${ }^{1, *}$, Aline Dia ${ }^{1}$, Mélanie Davranche ${ }^{1}$, Jérôme Molénat ${ }^{3}$

${ }^{1}$ CNRS, UMR 6118, Géosciences Rennes, Université Rennes 1, FR CAREN, Campus Beaulieu, 35042 Rennes Cedex, France

${ }^{2}$ Institut Polytechnique LaSalle-Beauvais, Département Géosciences, 19 rue Pierre Waguet, 60026

Beauvais Cedex, France

${ }^{3}$ INRA-Agrocampus Rennes, UMR 1069 Sol, Agronomie Spatialisation, FR CAREN, 65 rue de SaintBrieuc, 35042 Rennes Cedex, France

${ }^{\S}$ Tel.: +33 344068 979; Fax: + 33344062 526. E-mail address: olivier.pourret@lasalle-beauvais.fr *Tel.: +33 223236 086; Fax: + 33223235 787. E-mail address: gruau@univ-rennes1.fr 
Abstract A 7-year monitoring period of rare earth element (REE) concentrations and REE pattern shapes was carried out in well water samples from a $450 \mathrm{~m}$ long transect set up in the Kervidy/CoëtDan experimental catchment, France. The new dataset confirms systematic, topography-related REE signatures and REE concentrations variability but challenges the validity of a groundwater mixing hypothesis. Most likely, this is due to REE preferential adsorption upon mixing. However, the coupled mixing-adsorption mechanism still fails to explain the strong spatial variation in negative Ce anomaly amplitude. A third mechanism - namely, the input into the aquifer of REE-rich, Ce anomaly-free, organic colloids - is required to account for this variation. Ultrafiltration results and speciation calculations made using Model VI agree with this interpretation. Indeed, the data reveal that Ce anomaly amplitude downslope decrease corresponds to REE speciation change, downhill groundwaters REE being mainly bound to organic colloids. Water table depth monitoring shows that the colloid source is located in the uppermost, organic-rich soil horizons, and that the colloid input occurs mainly when water table rises in response to rainfall events. It appears that the colloids amount that reaches groundwater increases downhill as the distance between soil organic-rich horizons and water table decreases. Topography is, therefore, the ultimate key factor that controls Ce anomaly spatial variability in these shallow groundwaters. Finally, the $<0.2 \mu \mathrm{m}$ REE fraction ultimately comes from two solid sources in these groundwaters: one located in the deep basement schist; another located in the upper, organic-rich soil horizon.

Keywords rare earth elements; dissolved organic matter; speciation modeling; natural waters; ultrafiltration 


\section{Introduction}

Numerous studies over the past two decades have been dedicated to the aquatic geochemistry of rare earth elements (REE) (Byrne and Sholkovitz 1996; De Baar et al. 1988; De Baar et al. 1991; Duncan and Shaw 2003; Elderfield and Greaves 1982; Elderfield et al. 1990; Gosselin et al. 1992; Johannesson et al. 1997; 2000; Johannesson and Hendry 2000; Lawrence et al. 2006; Sholkovitz 1995; Smedley 1991). In particular, REEs have received much attention from hydrochemists in recent years because of their potential to be used as sensitive tracers of water-rock interaction processes and/or of groundwater mixing. However, this use of REE has to be developed with caution regard to the numerous processes and factors that may modify REE signatures in groundwaters. For example, processes such as REE complexation by inorganic ligands, or REE adsorption onto mineral phases can fractionate the REE patterns inherited from aquifer materials (e.g., De Carlo et al. 1998; Coppin et al. 2002; Johannesson et al. 1999; Tang and Johannesson 2005). REE complexation with natural organic ligands can also affect REE signatures of shallow groundwaters (Dia et al. 2000; Dupré et al. 1999; Ingri et al. 2000; Johannesson et al. 2004; Pourret et al. 2007a, b; Sonke and Salters 2006; Stern et al. 2007; Tanizaki et al. 1992; Viers et al. 1997), as can changes in pH that influence REE adsorption behavior (e.g., Byrne and Sholkovitz 1996; Johannesson and Burdige 2007). A thorough knowledge of the processes and factors that control REE concentrations and REE patterns in groundwater is thus required before the REE can be used as reliable hydrochemical tracers.

In this respect, it is important to understand the origin and significance of the systematic, topography-related spatial variability of REE signatures that occur in shallow groundwaters flowing in aquifer rocks of homogeneous composition. Three studies conducted on such groundwaters from Western Europe (Kervidy/Coët-Dan; Dia et al. 2000 and Petit Hermitage catchments; Gruau et al. 2004) and Western Africa (Goyoum area; Braun et al. 1998) indeed revealed the same extreme spatial variation of REE signatures. In all three cases, the same progressive disappearance of a negative Ce anomaly (i.e., registering redox equilibrium between dissolved $\mathrm{Ce}^{3+}$ and $\mathrm{Ce}^{4+}$ species) and the same progressive decrease in REE concentrations and of the Light REE (LREE; i.e., from La to Eu) over the Heavy REE (HREE; i.e., from Gd to Lu) ratio appear from top to bottom of the toposequence. In the case of the Kervidy/Coët-Dan catchment, this spatial change in REE signatures was interpreted as due to groundwater mixing processes (Dia et al. 2000). 
However, bottomland domain groundwaters showing no negative Ce anomaly are generally organic rich and less acidic than groundwaters from upland domains showing a large negative Ce anomaly (e.g., Gruau et al. 2004). Thus, it is possible that other factors such as pH variation and/or organic matter complexation also play a role in the observed gradients. In this study, the spatial variation of REE signatures in the shallow groundwaters of the Kervidy/Coët-Dan catchment (France) was re-investigated in more detail. This was realized by the regular sampling of these groundwaters over a seven-year period (from March 2000 to July 2007) coupled with ultrafiltration experiments (i.e., $30 \mathrm{kDa}, 10 \mathrm{kDa}$ and $5 \mathrm{kDa}$ ) and speciation modeling using the Humic Ion-Binding Model VI (Tipping, 1998). The primary aims of this study are (i) to test the temporal stability of the spatially variable REE signatures that occur in these groundwaters; (ii) to evaluate the respective roles of organic matter, $\mathrm{pH}$ and groundwater mixing on this variation and (iii) to identify the ultimate sources of REE in the aquifer system.

\section{Hydrogeology and previous hydrochemical data}

The Kervidy/Coët-Dan catchment is located in Naizin, a small rural village located in the center of Brittany, France (latitude: 48; longitude: $357^{\circ}$ 10’; Fig. 1) and supplies the Coët-Dan tributary of the Evel river. The catchment drains a surface of $4.9 \mathrm{~km}^{2}$. The Kervidy/Coët-Dan catchment is a sub-basin of the Naizin catchment $\left(12 \mathrm{~km}^{2}\right)$. The bedrock is made of fissured and fractured upper Proterozoic schists (Dabard et al. 1996). The soils, developed into a loamy material derived from bedrock weathering and eolian Quaternary deposits, exhibit facies variations, which are locally, dominated by silt, clay or sandstone materials (Pellerin and Van Vliet-Lanoë 1998). The mineralogical composition of schist was determined from drill-cutting analysis and includes (in decreasing relative proportion) quartz, muscovite, chlorite, K-feldspar and plagioclase (Pauwels et al. 1998). The soil horizons comprise a large number of secondary mineral phases including illite, smectite, kaolinite, various Fe-oxides and Fe-oxyhydroxides (hematite, goethite...) and Mn oxides (Pauwels et al. 1998). Both the soils and the bedrock schist of the Kervidy/Coët-Dan catchment display shale-like REE pattern signatures (Dia et al. 2000). (LREE/HREE) UCC ratios vary little from the soil surface down to the fresh schist horizons, always remaining close to 1.0. UCC subscript refers to normalization with respect to the estimated average composition of the Upper Continental Crust (UCC; 
Taylor and McLennan 1985). Moreover, negative Ce anomalies are not observed, neither in the fresh schist nor in the different soil horizons (Fig. 6 in Dia et al. 2000).

The land use in the Kervidy/Coët-Dan catchment is intensive farming dominated by maize, wheat and temporary pastures for dairy production and a high density of indoor pig-stock breeding. This land use has caused heavy nitrate pollution of the catchment waters with a mean nitrate concentration in the upland up to $140 \mathrm{mg} \mathrm{L}^{-1} \mathrm{NO}_{3}{ }^{-}$, which decreased along the flow paths toward the stream to ca. $80 \mathrm{mg} \mathrm{L}^{-1} \mathrm{NO}_{3}^{-}$(Molénat et al. 2002; 2008).

Previous hydrochemical studies (Dia et al. 2000; Durand and Juan Torres 1996; Molénat et al. 2002; 2008) showed that the Kervidy/Coët-Dan groundwater could be summarized by two spatially distributed hydrogeological and chemical domains. The first domain includes the bottomland areas or wetland domains. In these domains, the water table usually reaches the organic-rich upper soil horizons during the wet season (Fig. 1), namely, in winter and spring, leading to development of temporary reducing conditions. The shallowest levels of the water table (i.e., $<1 \mathrm{~m}$ deep) in the wetlands comprise colored, DOC-rich $\left(5<\right.$ DOC $\left.<40 \mathrm{mg} \mathrm{L}^{-1}\right)$ groundwater, whereas deeper in the water table (i.e., $>1 \mathrm{~m}$ deep), groundwater is colorless and DOC-poor (i.e., $<5 \mathrm{mg} \mathrm{L}^{-1}$ ). Nitrate, sulfate and REE concentrations vary vertically in the wetland groundwaters. In general, nitrate concentrations are low $\left(<0.1 \mathrm{mg} \mathrm{L}^{-1}\right)$ in the upper $(<1 \mathrm{~m})$, organic-rich $\left(<30 \mathrm{mg} \mathrm{L}^{-1}\right)$ groundwater, high below $1 \mathrm{~m}$ (up to 50 $\mathrm{mg} \mathrm{L}{ }^{-1}$ ), then decreasing again below $3 \mathrm{~m}$ to reach $0 \mathrm{mg} \mathrm{L}^{-1}$ at a depth of ca. $4 \mathrm{~m}$. REE concentrations are high in the shallow organic-rich groundwater (up to $15 \mu \mathrm{g} \mathrm{L}^{-1}$ ), then decreasing with depth (i.e., at higher than $4 \mathrm{~m}$ depth) to reach $10^{-2}$ times this concentration. Sulfate concentration varies oppositely with the highest concentrations (ca. $16 \mathrm{mg} \mathrm{L}^{-1}$ ) below $4 \mathrm{~m}$. The second domain includes the hillslope domains, where the water table always remains a few meters below the soil surface (Fig. 1). Groundwaters in these domains are always oxidizing, colorless, and DOC-poor (DOC $<5 \mathrm{mg} \mathrm{L}^{-1}$ ). As in the wetland domains, the composition of the groundwater below the hillslope domains varies vertically: above ca. $15 \mathrm{~m}$, groundwaters exhibit high nitrate (up to $200 \mathrm{mg} \mathrm{L}^{-1}$, locally), high REE (up to $\left.30 \mu \mathrm{g} \mathrm{L}{ }^{-1}\right)$, but low sulfate concentrations $\left(<5 \mathrm{mg} \mathrm{L}^{-1}\right)$. By contrast, below $15 \mathrm{~m}$, nitrate and REE concentrations are much lower, (close to $0.2 \mathrm{mg} \mathrm{L}^{-1}$, detection limit, and $<0.1 \mu \mathrm{g} \mathrm{L}^{-1}$, respectively), whereas sulfate concentrations increase markedly, from $1 \mathrm{mg} \mathrm{L}^{-1}$ to $20 \mathrm{mg} \mathrm{L}^{-1}$. 
Previous investigations of the REE geochemistry in groundwaters of the Kervidy/Coët-Dan catchment (Dia et al. 2000; Pourret et al. 2007a, b) showed a systematic, topography-related variation of REE signatures in the upper part (i.e., at depth between ca. 3 and $15 \mathrm{~m}$ ) of the DOC-poor groundwater. An upslope development of a large, negative Ce anomaly and a progressive enrichment of the LREE over the HREE were also noted. Based on the chemical variability of the groundwater composition with depth and taking into account the hydrological modeling studies, this topographyrelated variation of groundwater REE signatures was interpreted as a progressive mixing along the hillslope of the upper nitrate and REE-rich water in the upland domain and a return flow of the deep, denitrified, REE-poor groundwater. Secondly, it was demonstrated that REE in the DOC-rich, uppermost part (i.e., $<1 \mathrm{~m}$ ) of the wetland water table did not occur as free dissolved species but were bound to organic colloids (Pourret et al. 2007a, b). As previously shown by Davranche et al. (2005; 2008) and Pourret et al. (2007a) the organic speciation of the REE prevent any oxidative scavenging and preferential removal of Ce from the solution, hence explaining why these waters do not show any negative Ce anomaly.

\section{Sampling and analytical procedure}

Six wells were sampled for the purpose of this study. These six wells (PG1 to PG6) all come from a transect set perpendicular to the topographic slope (i.e., along a direction parallel to the groundwater flow path) in the eastern part of the catchment the so-called Guériniec transect (Fig. 1). These wells collect groundwater at a depth between - 3 to - $6 \mathrm{~m}$. Water samples were regularly collected (every three months on average) from March 2000 to July 2007.

\subsection{Field measurements and sample preparation}

Physico-chemical parameters ( $\mathrm{pH}$, Eh, temperature and conductivity) were directly measured in the field. The $\mathrm{pH}$ was measured with a combined Sentix 50 electrode after a calibration performed with WTW standard solutions ( $\mathrm{pH}=4.01$ and 7.00 at $\left.25^{\circ} \mathrm{C}\right)$. The accuracy of the $\mathrm{pH}$ measurement is $\pm 0.05 \mathrm{pH}$ unit. Conductivity was measured with a special conductivity cell (WTW TetraCon 325). Conductivity $(\sigma)$ values are presented in $\mu \mathrm{S} \mathrm{cm}^{-1}$. Eh was measured using a platinum combination 
electrode (Metler Pt 4805). Electrodes are inserted into a cell constructed to minimize diffusion of atmospheric oxygen into the sample during measurement. Eh values are presented in $\mathrm{mV}$ relative to standard hydrogen electrode.

Groundwater samples were pumped using Teflon tubing connected to a polyethylene syringe. About $60 \mathrm{~mL}$ of each sample was immediately filtered on site through $0.2 \mu \mathrm{m}$ cellulose acetate filter (Sartorius Minisart). An aliquot of $30 \mathrm{~mL}$ was acidified and subsequently used to measure REE concentrations. The remaining $30 \mathrm{~mL}$ was not acidified and used to measure alkalinity (only for May and November 2004 sampling campaign), nitrate, sulfate and DOC concentrations. During the November 2004 sampling campaign, an extra 1 L aliquot was collected from PG3 and PG4 piezometers to perform ultrafiltration experiments. This extra aliquot was filtered in the laboratory through $0.2 \mu \mathrm{m}$ cellulose acetate membrane using a Sartorius Teflon filtration unit. Thirty mL of the filtrate was acidified and used to measure REE concentrations, while $10 \mathrm{~mL}$ was used to measure nitrate, sulfate and DOC content. Ultrafiltration experiments were performed with the remaining filtrate.

3.2 Ultrafiltration

Ultrafiltration experiments were performed using $15 \mathrm{~mL}$ centrifugal tubes (Millipore Amicon Ultra-15) equipped with permeable membranes of decreasing pore sizes ( $<30 \mathrm{kDa},<10 \mathrm{kDa}$, and $<5$ $\mathrm{kDa}$ with $1 \mathrm{Da}$ (Dalton) $=1 \mathrm{~g} \mathrm{~mol}^{-1}$ for $\mathrm{H}$ ). Each centrifugal filter device was washed and rinsed with HCl $0.1 \mathrm{~mol} \mathrm{~L}^{-1}$ and MilliQ water twice before use. The starting filtrate was passed through $0.2 \mu \mathrm{m}$ filter, and then aliquots of these filtrates were passed through membranes of smaller pore sizes. All ultrafiltrations of the $0.2 \mu \mathrm{m}$ filtrates were done in parallel. The centrifugations were performed using a Jouan G4.12 centrifuge equipped with swinging bucket at about $3000 \mathrm{~g}$ for $20 \mathrm{~min}$ and $30 \mathrm{~min}$, for 30 $\mathrm{kDa}$ and $10 \mathrm{kDa}$ and $5 \mathrm{kDa}$ devices, respectively. All experiments were carried out at room temperature: $20 \pm 2{ }^{\circ} \mathrm{C}$. The ultrafiltration procedure prevents any mass balance between the filtrate and the retentate to be achieved because the retentate volumes are limited $(0.2 \mathrm{~mL})$. However, as the same material was used for all filtrations, molecular size exclusion rather than adsorption onto membranes should control the colloid distributions between ultrafiltrates. Such a feature has been further tested using synthetic REE solution (Pourret et al. 2007c). All ultrafiltrations were performed in 
duplicates. A good reproducibility was observed for DOC and major and trace elements concentrations. Duplicates were better than $5 \%$ for most elements except for some trace elements in the lower pore size cutoff fraction (i.e., in the $<5 \mathrm{kDa}$ fraction, about $10 \%$ ). Further information on the ultrafiltration procedure can be found in Pourret et al. (2007b).

\subsection{Chemical analyses}

Major anions $\left(\mathrm{SO}_{4}{ }^{2-}\right.$ and $\left.\mathrm{NO}_{3}{ }^{-}\right)$concentrations were measured by ionic chromatography (Dionex DX-120) with an uncertainty below $\pm 4 \%$ (by using a Dionex seven anions standard solution). Rare earth element concentrations were determined by ICPMS (Agilent 4500), using indium as an internal standard. The method is described in more detail in Davranche et al. (2004). The international geostandard SLRS-4 was used to check the validity and reproducibility of the results. Typical uncertainties including all error sources are below $\pm 5 \%$ for all the trace elements, whereas for major cations, the uncertainty lies between $\pm 2 \%$ and $\pm 5 \%$, depending on the concentration levels. Dissolved organic carbon concentrations were analyzed on a total organic carbon analyzer (Shimadzu TOC$5050 \mathrm{~A}$ ). Accuracy of DOC measurement is estimated at $\pm 5 \%$ (by using a standard solution of Kbiphtalate). Alkalinity was determined by potentiometric titration with an automatic titrating device (794 Basic Titrino Methrom). The uncertainty is better than 5\%.

All procedures (sampling, filtration, storing and analysis) were carried out in order to minimize contamination. Samples were stored in acid-washed Nalgene polypropylene containers

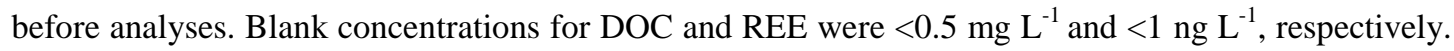
All reported DOC concentrations are blank corrected (maximum correction $=8 \%$ ). For the REE, there was no need for blank corrections, because the sample concentrations were systematically two to three orders of magnitude higher than blank levels. The instrumental error on REE analysis in our laboratory, as established from repeated analyses of multi-REE standard solution (Accu Trace ${ }^{\mathrm{TM}}$ Reference, USA) and of the SLRS-4 water standard, is below 2\% (e.g., Davranche et al. 2004; Yeghicheyan et al. 2001). Interference corrections are detailed in Davranche et al. (2004).

\subsection{Speciation calculation}


Speciation calculations were performed using the computer program WHAM 6 (Version 6.0.13) including Humic Ion-Binding Model VI (Model VI; Tipping 1998). It was used to calculate the speciation of REE in three wells, namely, PG3, PG4 and PG5 sampled in May and November 2004. It must be unfortunately noted that data necessary to model speciation were only available for these three wells (PG6 well was empty as the water table was below, and PG1 and PG2 REE concentrations were below the detection limits at these two sampling dates). Model VI was modified by building a database that included $\log \mathrm{K}_{\mathrm{MA}}$ for the whole REE series and values for REE complexation with HM, along with well-accepted infinite-dilution $\left(25^{\circ} \mathrm{C}\right)$ stability constants for REE inorganic complexes (hydroxide, sulfate and carbonate; Klungness and Byrne 2000; Luo and Byrne 2004; Schijf and Byrne 2004). Model VI is described in more detail in Tipping (1998), and adaptation of Model VI to REE is detailed in Pourret et al. (2007a; 2007c). Model VI parameters for humic acid (HA) and fulvic acid (FA) and REE are presented in Table A1. As Model VI does not consider saturation index and mineral precipitation, inorganic speciation was further performed using PHREEQC (Parkhurst and Appelo 1999). For this purpose, Nagra/PSI database (Hummel et al. 2002) was used and updated including the same well-accepted infinite-dilution $\left(25^{\circ} \mathrm{C}\right)$ stability constants for REE inorganic complexes (hydroxide, sulfate and carbonate; Klungness and Byrne 2000; Luo and Byrne 2004; Schijf and Byrne 2004).

\section{Results}

4.1 Spatial variability of water chemistry and REE signatures

The entire dataset can be obtained from the authors on request. Average REE, DOC, $\mathrm{SO}_{4}{ }^{2-}$, $\mathrm{NO}_{3}{ }^{-}$, major cations (including $\mathrm{Mn}$ and $\mathrm{Fe}$ ), Eh, conductivity, temperature and alkalinity concentrations, as well as average $\mathrm{pH}$ values for the six investigated wells are presented in Table 1 and further displayed on Figure 2. REE patterns are portrayed in Figure 3.

As can be seen on Figure 2, $\mathrm{SO}_{4}{ }^{2-}$ concentrations increase (from 0.7 to $16.8 \mathrm{mg} \mathrm{L}^{-1}$ ) as groundwater moves downslope toward the stream, whereas $\mathrm{NO}_{3}{ }^{-}$concentrations show the opposite trend (i.e., concentrations decrease along the same flow path: from 124 to $\leq 1 \mathrm{mg} \mathrm{L}{ }^{-1}$ ). The $\mathrm{pH}$ values also vary spatially, with groundwaters from upland wells PG6 and PG5 being slightly more acidic (i.e., 
pH between 5.6 and 5.8) than groundwaters from bottomland wells PG1 and PG2 (i.e., pH between 6.5 and 6.2). Groundwaters are oxidized and display relatively the same oxidation state (Eh values ranging from $484 \mathrm{mV}$ to $406 \mathrm{mV}$, from top to bottom of the toposequence). Alkalinity values determined during May 2004 and November 2004 were lower in upland domain wells (i.e., 100 to $300 \mu$ mol L ${ }^{-1}$ for PG5 water) compared to bottomland wells (i.e., between 1,241 to 3,741 $\mu \mathrm{mol} \mathrm{L}^{-1}$ in PG1 well). This increase in alkalinity values downslope is consistent with the observed downslope $\mathrm{pH}$ increase (from 5.4 to 6.6 on May 2004, and from 6.0 to 7.1 on November 2004 from PG5 to PG1, respectively). Major elements and $\mathrm{pH}$ variations thus provide signature of end-members and help validating the water mixing model that consist of a mixing of nitrate-rich, low $\mathrm{pH}$ subsurface water with nitrate-poor, comparatively higher pH, deep groundwater in agreement with studies of Dia et al. (2000) and Molénat et al. (2002).

REE concentrations and profiles also exhibit a systematic spatial variability in these groundwaters, thereby confirming the previous findings by Dia et al. (2000). As can be seen in Figures 1 and 3, REE concentrations progressively decrease from wells PG6 to PG1 (from 17.3 to $0.028 \mathrm{mg} \mathrm{L}^{-}$ ${ }^{1}$, on average). The size of the negative Ce anomaly progressively decreases along the inferred groundwater flow path as well $(\mathrm{Ce} / \mathrm{Ce} *=0.07$ in $\mathrm{PG} 5$ groundwater compared to 0.77 in $\mathrm{PG} 1$ groundwater; Fig. 4). Secondly, a progressive depletion of the LREE over the HREE is noted from PG6 ((LREE/HREE) $\left.)_{\mathrm{UCC}}=3.2\right)$ to PG1 wells $\left((\text { LREE/HREE })_{\mathrm{UCC}}=0.9 ;\right.$ Fig. 4).

\subsection{Temporal stability of REE signatures}

Although REE patterns shape widely spatially vary in Guériniec groundwaters, they appear to be remarkably temporally stable. Indeed, both the Ce/Ce* value and the (LREE/HREE) UcC ratio remain virtually constant in any given piezometer (Fig. 4). This feature was already emphasized by Dia et al. (2000) and Olivié-Lauquet et al. (2001). However, the temporal stability of the REE pattern shapes in Guériniec groundwaters was established at that time only for one hydrological year. With the new dataset, the temporal stability is demonstrated to exist over a much longer period of time (seven-year period), thereby demonstrating that the observed REE variations are long-term, and stationary, key features of these groundwaters.

\subsection{REE speciation}




\subsubsection{Ultrafiltration data}

In order to establish the role of organic colloids on REE concentrations and REE pattern shapes, waters from two Guériniec wells (i.e., PG3 and PG4) were successively filtered through membranes of decreasing pore size (i.e., $<30 \mathrm{kDa},<10 \mathrm{kDa}$ and $<5 \mathrm{kDa}$; Table 2). As expected, both DOC and REE concentrations decreased upon successive filtrations (Fig. 5a and 5b), suggesting that part of the REE is effectively complexed by organic colloids in these waters. The possibility that REE were associated with $\mathrm{FeOOH}$ colloid was eliminated as iron is present under free and complexed Fe(III) species to dissolved organic matter (Lofts et al. 2008; Pokrovsky et al. 2005; Pourret et al. 2007b). The shape of the REE patterns remains globally unchanged, even though a slight $\mathrm{Ce} / \mathrm{Ce}{ }^{*}$ ratio decrease occurred in the most organic-rich sample (i.e., Ce/Ce* decreasing from 0.58 to 0.41 in PG3 water with DOC of 4.3 $\mathrm{mg} \mathrm{L}^{-1}$ ). However, differences regarding the quantitative partitioning of the REE between the organic and inorganic phases of the samples were noted. Indeed, comparison between REE concentrations in the $<5 \mathrm{kDa}$ and $<0.2 \mu \mathrm{m}$ solutions implies that about $56 \%$ of the REE in PG3 groundwater occur as colloidal compounds, against only $21 \%$ in PG4 groundwater. Albeit it should be noted that such observation was only made on replicates from two samples. However, Dia et al. (2000) reported an even smaller fraction of colloidal REE for PG5 water (6\%). Thus, it appears that the changes in negative Ce anomaly amplitude and (LREE/HREE) UcC $_{\text {ratios that are observed along the Guériniec }}$ toposequence occur simultaneously with changes in REE speciation. Indeed, REEs in upland domain waters show low Ce/Ce* ratios (i.e., large negative Ce anomalies) and high (LREE/HREE) Ucc and speciation is dominated by REE inorganic species, whereas REE in waters showing high Ce/Ce* ratios

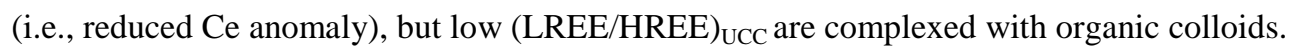

\subsubsection{Modeling results}

Model VI (Tipping 1998) was used to calculate REE speciation in PG3, PG4 and PG5 groundwaters, and the results were compared to the earlier mentioned ultrafiltration data. Major cation and anion concentrations and $\mathrm{Fe}$ and $\mathrm{Al}$ concentrations were taken into account in these calculations. In WHAM 6.0 (Tipping 1998), no solid precipitation is allowed to occur. Only complexation, either by organic colloids or by aqueous inorganic complexes, is modeled. In this study, it is assumed that $50 \%$ 
of the dissolved organic matter (DOM) is active as REE-complexing, humic matter (HM) (Thurman, 1985), of which $80 \%$ is present as HA and $20 \%$ as FA (Pourret et al. 2007a; Viers et al. 1997). Even if this active DOM ratio could be higher than $50 \%$, such a value is a good compromise (see sensitive analysis in Pourret et al. 2007a).

The modeling results are displayed in Table 3 for La (La-HA and La-FA species are gathered together under La-HM). Modeling results for the others REE are coherent with La (data not shown). Consistently with the ultrafiltration results, speciation calculations show that La-HM is the dominant La species in PG3 groundwater (between $92.5 \%$ and $100 \%$ depending on the sampling date). Conversely, but also consistently with the ultrafiltration results, the proportion of La complexed with HM is lower in PG4 and PG5 groundwaters. Indeed, between 67\% and 49\% of La occur as free inorganic species in PG4 groundwater, and 75\% in PG5 groundwater. In PG4 groundwater, the remaining La occurs as sulfate (from 6.0\% to 7.1\%) and La-HM complexes (from 26.1\% to 43.1\%). Other species consist of La hydroxide or carbonate complexes. Moreover, PHREEQC inorganic speciation does not evidence any peculiar mineral precipitation involving REE.

The modeling calculations thus demonstrate the same progressive spatial change in REE speciation as that evidenced by the ultrafiltration experiments (predominance of inorganic species in upland domain groundwaters against predominance of organic colloidal REE complexes in bottom land groundwaters). They also demonstrate that the observed spatial variability in REE speciation is likely a stable feature of these groundwaters, given that the good agreement observed between the present modeling and ultrafiltration data and the ultrafiltration data published previously by Dia et al. (2000).

\section{Discussion}

The new REE data reported for Guériniec groundwaters confirm the spatial variability of REE signatures established previously by Dia et al. (2000) for this groundwater system. The new dataset is especially significant becuase both REE pattern shape and Ce anomaly amplitude spatial variability are proved to be stationary on a seven-year period. It is also significant that REE signatures and Ce anomaly amplitude spatial variability also corresponds to REE speciation spatial variability: REE become progressively more organically bound downslope. In this context, three important questions arise: (i) Is the hypothesis previously put forward by Dia et al. (2000) of a spatial variability of REE 
signatures due to a mixing process confirmed? (ii) What is the role of REE speciation on the spatial variation of REE concentrations and REE signatures? (iii) How do the Guériniec groundwaters compare themselves with similar shallow groundwaters elsewhere in the world, and what are the ultimate REE sources in these groundwaters?

5.1 The role of groundwater mixing and $\mathrm{pH}$ variation on REE signatures

In their paper, Dia et al. (2000) concluded that the progressive change in dissolved REE signature from top to bottom of the toposequence may indicate a progressive mixing phenomenon along the hillslope between a nitrate-rich water coming from the recharge zone in the upland domain (i.e., a water similar in composition to PG6 groundwater) and a return flow water comprising deep, denitrified water (i.e., a water similar in composition to PG2 groundwater). The occurrence of such a progressive mixing phenomenon along the Guériniec transect is confirmed by this new dataset, specifically by the $\mathrm{SO}_{4}{ }^{2-}$ and $\mathrm{NO}_{3}{ }^{-}$concentrations that define a mixing line relationship (see section 4.1 and Fig. 6a). As evidenced earlier by Molénat et al. (2002), a dilution mechanism occurs between these two end-members. However, the two components mixing hypothesis failed to explain the variation in REE concentrations. Actually, REE concentrations do not define a mixing line when reported along with $\mathrm{NO}_{3}^{-}$concentrations (Fig. 6b). This is due to a nonconservative behavior of the REE during mixing, likely caused by the $\mathrm{pH}$ increase that accompanies the groundwater mixing process (Fig. 2).

As shown by Elderfield et al. (1990), REE concentrations in waters are indeed highly $\mathrm{pH}$ dependent: high $\mathrm{pH}$ results in low REE concentrations. Changes in $\mathrm{pH}$ can also fractionate dissolved REE patterns (Koeppenkastrop and De Carlo 1992; 1993; Ohta and Kawabe 2001). Alkaline pH results in waters being relatively enriched in HREE, which contrasts with more acidic waters in which the REE patterns generally exhibit relative LREE enrichments (e.g., Andersson et al. 2006). This behavior is due the fact that REE are preferentially adsorbed onto aquifer minerals when $\mathrm{pH}$ increases and that LREE generally adsorb more efficiently onto solid phases than HREE do. At high pH, the deprotonation of surface hydroxyl groups generates a negative charge onto mineral surfaces, favoring adsorption of positively charged REE. With increasing $\mathrm{pH}$, the order of REE adsorption onto mineral surfaces is LREE $>$ MREE $>$ HREE. With decreasing $\mathrm{pH}$, REEs are released from mineral surfaces in the same order, LREE>MREE>HREE (Gammons et al. 2005; Johannesson et al. 2006; Leybourne and 
Johannesson 2008; Sholkovitz 1995; Welch et al. 2009). Thus, REE concentrations and REE pattern shapes in groundwaters are determined to a large extent by $\mathrm{pH}$-driven adsorption/desorption reactions between the solution and mineral surfaces.

As shown in Figure 2, the groundwater mixing that occurs along the Guériniec transect does not occur at constant pH. As evidenced by Molénat et al. (2002), the evolution of the weathered aquifer along flow path could be due to upward flows. The pH of Guériniec groundwaters indeed increases from top ( $\mathrm{pH}=5.6$, on average) to bottom ( $\mathrm{pH}=6.5$, on average) of the toposequence, implying that PG6 groundwater, the high REE content mixing end-member, experiences a marked pH increase when mix together with the low REE PG1 groundwater end-member. This $\mathrm{pH}$ increase must result in a partial adsorption of the REE brought about by PG6 groundwater, thereby explaining why REE concentrations and $\mathrm{pH}$ are inversely correlated in Guériniec groundwaters (Fig. 7). It should be noted that speciation calculation evidenced that none REE minerals precipitation occurs in the system. Similar negative relationships between $\mathrm{pH}$ and REE concentrations have already been reported for neutral to slightly acidic waters (e.g., Byrne and Sholkovitz 1996; Goldstein and Jacobsen 1988; Johannesson and Burdige 2007).

The (LREE/HREE) UcC ratio decrease that follows the REE concentrations decrease along the Guériniec toposequence supports the earlier mentionned conclusion of a nonconservative mixing due to REE adsorption in response to $\mathrm{pH}$ rise. Indeed, LREE preferentially adsorbed onto mineral aquifers as compared to HREE (e.g., Gammons et al. 2005). A decrease in (LREE/HREE) UcC $_{\text {is }}$ thus a fully expected feature in groundwaters subjected to progressive adsorption of their dissolved REE onto mineral aquifers in response to $\mathrm{pH}$ increase (e.g., Johannesson and Burdige 2007).

\subsection{Origin of negative Ce anomaly variations}

The second most important feature displayed by the Guériniec groundwaters is that Ce anomaly gets smaller from top to bottom of the toposequence (Fig. 3). The next question to be answered is, thus, could the combined groundwater mixing and REE adsorption process also account for the spatial variation in Ce anomaly amplitude?

A simple mixing model was developed to evaluate this possibility. In this model, $\mathrm{NO}_{3}{ }^{-}$ concentrations were used to calculate the proportions of the two end-member groundwaters (i.e., PG6 
and PG1) that should be mixed to account for PG5, PG4, PG3 and PG2 groundwater compositions. The proportions of PG6 groundwater obtained this way were 63\% for PG5, 42\% for PG4, 16\% for PG3 and 10\% for PG2. To model the decrease in REE concentration due to adsorption, a three-step approach was followed: (i) the average pH value measured in PG5, PG4, PG3 and PG2 well waters was inputted into equation 1 (i.e., regression line from Fig. 7).

$$
\mathrm{pH}=-0.14 \ln (\Sigma \mathrm{REE})+6.02
$$

This allowed calculating REE amount that should be obtained in PG5, PG4, PG3 and PG2 well waters after mixing; (ii) because REE in the mixture must dominantly come from PG6 groundwater (i.e., REE content of PG6 groundwater is higher about three orders of magnitude than that of PG1; Table 1), the REE concentration decrease that occurred during mixing could be essentially modeled by diluting PG6 groundwater before mixing. Dilution factors were calculated by dividing the measured average REE content of PG6 by the REE concentrations one should be obtained for PG5, PG4, PG3 and PG2 groundwaters as indicated by Figure 7; (iii) in the final step, diluted PG6 concentrations were inputted into the mixing equation and REE concentrations and Ce/Ce* ratios calculated for PG2, PG3, PG4 and PG5 groundwaters.

It should be pointed out here that this simple model does not take into account the preferential adsorption of the LREE over the HREE onto the mineral aquifers. Indeed, the LREE/HRRE is kept constant during dilution of PG6 groundwater. However, the procedure used is judged valid with regard to the objective of the modeling (i.e., testing if the combined mixing-adsorption can account for the reduction in negative Ce anomaly amplitude), given the fact that the Ce anomaly amplitude in the mixture will depend essentially on only two parameters, namely, (i) the Ce anomaly amplitude of each end-member and (ii) the relative REE proportion brought about into the mixture by each end-member.

Results are presented in Figures 8a and 8b. As can be seen, the fit between modeled and measured values is quite good for REE concentrations (considering standard deviation, data plot on a 1:1 line), but poor for $\mathrm{Ce} / \mathrm{Ce} e^{*}$ ratios, three groundwaters (PG3, PG4 and PG5) yielding calculated $\mathrm{Ce} / \mathrm{Ce} *$ ratios that plot significantly below the 1:1 line (Fig. 8b). In other words, for these three groundwaters, the amplitude of the modeled negative Ce anomalies is much larger than that effectively measured. This discrepancy provides evidence that the downward decrease in the Ce anomaly amplitude along the Guériniec transect is not controlled by the combined mixing-adsorption process. A third mechanism is 
required. As discussed here, this third mechanism could be an organic colloid input. Three arguments support this interpretation:

(i) Except for the somewhat deeper PG1 groundwater (Fig. 1) with very low REE concentrations (Fig. 2), positive correlations are observed between REE and DOC contents in bottomland groundwaters exhibiting moderate negative Ce anomalies (i.e., PG2, PG3 and PG4; Fig. 9). Combined with ultrafiltration and speciation modeling data, this observation revealed that Ce anomaly amplitude decrease with an increase in the REE proportion bound to organic colloids. Moreover, ultrafiltration data show that negative Ce anomaly amplitude in PG3 ultrafiltrates increases with decreasing pore size (Table 2; Fig. 5). This indicates that colloidal fraction REE pattern present in PG3 either exhibits no negative Ce anomaly or, a negative Ce anomaly of much lower amplitude than that occurring in the truly dissolved, inorganic REE fraction of this sample. Thus, the DOC-Ce anomaly relationship of these downhill groundwaters looks just as if REE budget of these waters was a mixture between REE-bearing organic colloids having no or reduced Ce anomaly, and an inorganic REE pool having a marked negative Ce anomaly.

(ii) A classical feature of shallow water tables developed on low-permeability basement is that rainfall event during wet season generally result in a rapid and marked rise of the water table, the latter reaching the uppermost, organic rich soil horizons in the bottomland areas of the catchments. This water table rise may result in incorporation of large proportions of soil organic colloids into the uppermost parts of the shallow groundwater. Figure 10 compares the 2006-2007 fluctuations of the Guériniec water table roof with the DOC content and Ce anomaly amplitude of PG3 well water. The $2.5 \mathrm{~m}$ water table rise that occurs in October-November 2006 in response to intense autumn rainfalls resulted in a marked DOC content increase (from 1 to $8 \mathrm{mg} \mathrm{L}^{-1}$; Fig. 10a) of PG3 well water. Quite clearly, this increase occurred in phase with a marked increase in the $\mathrm{Ce} / \mathrm{Ce}$ * ratio (from 0.52 to 0.60 ; Fig. $10 \mathrm{~b})$.

(iii) As shown by Dia et al. (2000) and Pourret et al. (2007a, 2007b), organic-rich soil horizons of the Kervidy/Coët-Dan catchment may deliver large quantities of REE-bearing organic colloids to the groundwaters. Moreover, and most importantly, REE patterns of 
these organic colloids do not show any negative Ce anomaly. Davranche et al. (2004, 2005, and 2008) experimentally demonstrated that REE complexation by organic matter prevents Ce oxidative scavenging by iron and manganese oxyhydroxides (and consequently the Ce anomaly development) and Pourret et al. (2008) proposed that the preferential $\mathrm{Ce}(\mathrm{IV})$ is masked rather than inhibited.

A simple modeling approach was used to further test the hypothesis of a Ce anomaly reduction due to REE-bearing organic colloids input. In this approach, REE amount brought by organic colloids into the Guériniec groundwater was calculated from the DOC content and the DOC/REE ratios measured by Dia et al. (2000) in PF1 and PF3 wells (i.e., the two wells installed on the Kervidy/CoëtDan catchment to monitor the composition of the groundwater that flows with the uppermost - between 20 and $50 \mathrm{~cm} \mathrm{-} \mathrm{organic} \mathrm{soil} \mathrm{horizons).} \mathrm{Initial} \mathrm{groundwater} \mathrm{REE} \mathrm{concentrations} \mathrm{(i.e.,} \mathrm{REE}$ concentrations in groundwater wells prior to colloid input) were calculated using the earlier described mixing-adsorption process. In other words, the amount of REE bring by the organic colloids was added to the previous calculations that considered only groundwater mixing and REE adsorption. Results are presented in Figure 11 which compares $\mathrm{Ce} / \mathrm{Ce} *$ ratios calculated by combining the earlier described mixing-adsorption mechanism and the proposed colloid input process, and $\mathrm{Ce} / \mathrm{Ce}{ }^{*}$ ratios effectively measured in Guériniec groundwaters. As can be seen, a reasonably good fit arises between measured and calculated $\mathrm{Ce} / \mathrm{Ce} *$ ratios (see legend of Fig. 11 for further explanation). Indeed, a colloidal addition of PF1 water type to the inorganic groundwater mixing allows to model PG2, whereas PF3 is required to model PG3 and PG4.

To sum up, the regular and progressive change in REE signatures and Ce anomaly amplitude that is recorded by Guériniec groundwaters likely arises from the superimposition of three processes (Fig. 12): (i) progressive mixing along the hillslope between a shallow, acidic, REE-rich groundwater component coming from the recharge zone in the upland domain and flowing downwards (flow path $\mathrm{n}^{\circ} 1$ ), and a deep, REE-poor, less-acidic groundwater component (flow path $\mathrm{n}^{\circ}$ ); (ii) adsorption of part of the dissolved REE brought about by the REE-rich component due to $\mathrm{pH}$ increase; (iii) addition of REE-bearing, Ce anomaly free organic colloids from the uppermost, organic-rich soil horizons (flow path $\left.n^{\circ} 3\right)$.

With regard to the latter process, topography is expected to play a dominant role on organic colloids amount that can effectively reach the Guériniec water table and, thus, on the colloid addition 
process capacity to reduce the negative Ce anomalies amplitude in these groundwaters. Topography is indeed expected to control the surface area in which the water table may rise into the soil uppermost, organic-rich horizons. More specifically, water table depth monitoring revealed that in the upland domains located above the convex-concave reversal of the topography the water table always remained well below the uppermost, organic-rich soil horizons (Fig. 1). Organic colloids flux in this domain is thus expected to be low. By contrast, in the bottomland domains, water table depth monitoring indicated that water table periodically reached soil surface during wet season (i.e., late fall and winter). The flux of organic colloids is, therefore, expected to be high in this domain, leading to a strong reduction of the negative Ce anomaly of the groundwater.

\subsection{Comparison with similar groundwaters and implications for REE sources}

As pointed out in the introduction, similar spatial variability of REE signatures and negative Ce anomaly amplitude has been reported in groundwaters of the Goyoum toposequence in Cameroon (Braun et al. 1998) and of the Le Home toposequence (Gruau et al. 2004) in Western France. As in the Guériniec case, both the Goyoum and Le Home groundwaters flow through aquifer rock of homogeneous composition: Proterozoic gneisses at Goyoum and Proterozoic schists at Le Home. In Figure 13, $\mathrm{Ce} / \mathrm{Ce} *$ ratios in these three-groundwater systems are reported as a function of the distance to the stream. Figure 13 shows that the three-groundwater systems plot along a single trend reflecting the Ce anomaly amplitude gradual reduction as the distance to the stream decreases. Thus, the Ce anomaly amplitude gradual reduction observed at Guériniec from top to bottom of the toposequence appears to be a general feature of shallow groundwaters flowing into aquifers developed onto low permeability bedrock. The likely reason for this mainly relies on the fact that, in low-permeability aquifers, water table generally reaches organic soil horizons in bottomland domains, thus allowing incorporation of large quantities of organic colloids in the aquifer bottomland part. This feature is not seen in the aquifer upland part where the water table always remains far below the upper, organic-rich soil horizons. This feature needs to be expanded to other toposequences in various hydrological contexts. Indeed, as stated by Köhler et al. (2009) in boreal catchments REE export is mostly strongly controlled by landscape type. 
Finally, consideration of Ce anomaly spatial variation requires the occurrence of two spatially distinct REE sources. More specifically, the presence of a large negative Ce anomaly in the upland groundwaters (e.g., PG5 well water) implies solubilization of the REE under organic-free, oxidizing conditions. Indeed, as shown by Davranche et al. (2005; 2008), the presence of organic matter inhibits the development of negative Ce anomalies in oxidizing waters, because Ce cannot be oxidized by oxidizing mineral surfaces such as Mn oxides and above all because Ce cannot be selectively removed from the solution, Ce being complexed together with other REE by organic molecules. Thus, the occurrence of groundwaters having large negative Ce anomalies (e.g., PG 5 and PG6 well waters) implies that REE in these groundwaters ultimately come from solid sources located in the aquifer where DOC concentrations are low and where REE speciation is consequently dominated by inorganic species. Conversely, the fact that REE patterns found in upper, organic-rich soil horizon waters do not exhibit any negative Ce anomaly implies to consider that REE became dissolved in these waters in an organic-rich environment. Should REE have been solubilized in a purely inorganic context similar to that encountered in the aquifer upland domain, then original REE patterns would had a negative Ce anomaly that should still be observed in the organic-rich waters. The fact that the organic-rich water does not show any negative Ce anomaly thus provides evidence that a second REE solid source must exist in the Guériniec aquifer. Unlike the first source that must be located deep, this second source must be located close to the surface, in the organic-rich soil horizons, i.e., in that part of the aquifer where the REE fully organic speciation makes negative Ce anomaly development impossible.

\section{Conclusions}

This paper presents new data on the REE chemistry of shallow groundwaters from the Guériniec transect of the Kervidy/Coët-Dan experimental catchment, Western France. The field database that covers a seven-year monitoring period is followed by results of ultrafiltration experiments and speciation calculations. This allows to further constraining the speciation of the dissolved REE. The new data confirmed the spatial variability of REE pattern shapes and Ce anomaly amplitude evidenced earlier in these groundwaters, which is shown to correspond to changes in REE speciation, REE in groundwaters from the bottom land domains of the toposequence being complexed by organic molecules, whereas those in groundwaters from the upland parts occur mainly as inorganic species. Simple modeling using variations in major anion concentrations and $\mathrm{pH}$ variations reveal that the 
variation in REE pattern shape and REE concentrations along the Guériniec transect may be accounted for by a combined mixing-adsorption process. However, the data show that a third mechanism of organic colloid addition must be introduced to account for the variation in Ce anomaly amplitude. According to water table depth-monitoring data, it is suggested that the colloid source is located in the uppermost, organic-rich horizons of the aquifer and that the colloid input (and thus the reduction of the Ce anomaly amplitude it implies) is high in the bottomland domains of the toposequence but low to very low in its upland domains. A comparison of the Guériniec data with data from other shallow groundwater systems from Cameroon and Western France indicates that the topographically controlled variation in Ce anomaly amplitude seems to be a common feature of these systems. Topography is indeed the ultimate key factor that controls the spatial variability of Ce anomaly in shallow groundwaters by its ability to control the thickness of the unsaturated zone, and consequently the flux of Ce anomaly free, organic-rich colloids that can effectively reach the water table. Finally, it is shown, based on the variations in Ce anomaly amplitude, that the $<0.2 \mu \mathrm{m}$ REE fraction ultimately comes from two solid sources in these groundwaters: one located in the deep basement schist; another located in the upper, organic-rich soil horizon.

Acknowledgements We thank the technical staff at Rennes (M. Le Coz-Bouhnik, O. Hénin and P. Petitjean) and the graduate/undergraduate students for their assistance during the sampling, and the analytical work. The CPER program “Développement de la Recherche sur la Maîtrise de la Qualité de l’Eau en Bretagne” jointly funded by the French Government and the Council of Rennes Métropole supported this research. C.H. Gammons and A.M. Shiller are thanked for thorough and constructive comments of an earlier version of this paper.

\section{Appendix}

\section{References}

Andersson K, Dahlqvist R, Turner D, Stolpe B, Larsson T, Ingri J, Andersson P (2006) Colloidal rare earth elements in boreal river: Changing sources and distributions during the spring flood. Geochim Cosmochim Acta 70: 3261-3274. doi:10.1016/j.gca.2006.04.021 
Braun JJ, Viers J, Dupré B, Polvé M, Ndam J, Muller JP (1998) Solid/liquid REE fractionation in the lateritic system of Goyoum, East Cameroon: the implication for the present dynamics of the soil covers of the humid tropical regions. Geochim Cosmochim Acta 62: 273-299. doi:10.1016/S0016-7037(97)00344-X

Byrne RH, Sholkovitz ER (1996) Marine chemistry and geochemistry of the lanthanides. In: Gschneidner Jr. KA, Eyring LR (eds) Handbook on the Physics and Chemistry of Rare Earths, Vol 23, Elsevier, Amsterdam, pp 497-593.

Coppin F, Berger G, Bauer A, Castet S, Loubet M (2002) Sorption of lanthanides on smectite and kaolinite. Chem Geol 182: 57-68. doi:10.1016/S0009-2541(01)00283-2

Dabard M-P, Loi A, Peucat J-J (1996) Zircon typology combined with Sm-Nd whole rock-isotope analysis to study Brioverian sediments from the Armorican Massif. Sediment Geol 101: 243260. doi:10.1016/0037-0738(95)00068-2

Davranche M, Pourret O, Gruau G, Dia A (2004) Impact of humate complexation on the adsorption of REE onto Fe oxyhydroxide. J Colloid Interface Sci 277: 271-279. doi:10.1016/j.jcis.2004.04.007

Davranche M, Pourret O, Gruau G, Dia A, Le Coz-Bouhnik M (2005) Adsorption of REE(III)-humate complexes onto $\mathrm{MnO}_{2}$ : Experimental evidence for cerium anomaly and lanthanide tetrad effect suppression. Geochim Cosmochim Acta 69: 4825-4835. doi:10.1016/j.gca.2005.06.005

Davranche M, Pourret O, Gruau G, Dia A, Jin D, Gaertner D (2008) Competitive binding of REE to humic acid and manganese oxide: impact of reaction kinetics on development of Cerium anomaly and REE adsorption. Chem Geol 247: 154-170. doi:10.1016/j.chemgeo.2007.10.010

De Baar HJW, German CR, Elderfield H, van Gaans P (1988) Rare earth element distributions in anoxic waters of the Cariaco Trench. Geochim Cosmochim Acta 52: 1203-1219. doi:10.1016/0016-7037(88)90275-X

De Baar HJW, Schijf J, Byrne RH (1991) Solution chemistry of the rare earth elements in seawater. Eur J Solid State Inorg Chem 28: 357-373.

De Carlo EH, Wen X-Y, Irving M (1998) The influence of redox reactions on the uptake of dissolved Ce by suspended $\mathrm{Fe}$ and $\mathrm{Mn}$ oxide particles. Aquat Geochem 3: 357-389. doi:10.1023/A:1009664626181 
Dia A, Gruau G, Olivié-Lauquet G, Riou C, Molénat J, Curmi P (2000) The distribution of rare earth elements in groundwaters: assessing the role of source-rock composition, redox changes and colloidal particle. Geochim Cosmochim Acta 64: 4131-4151. doi:10.1016/S00167037(00)00494-4

Duncan T, Shaw TJ (2003) The mobility of rare earth elements and redox sensitive elements in the groundwater/seawater mixing zone of a shallow coastal aquifer. Aquat Geochem 9: 223-255. doi: 10.1023/B:AQUA.0000022956.20338.26

Dupré B, Viers J, Dandurand J-L, Polvé M, Bénézeth P, Vervier P, Braun J-J (1999) Major and trace elements associated with colloids in organic-rich river waters: ultrafiltration of natural and spiked solutions. Chem Geol 160: 63-80. doi:10.1016/S0009-2541(99)00060-1

Durand P, Juan Torres JL (1996) Solute transfer in agricultural catchments: the interest and limits of mixing models. J Hydrol 181: 1-22. doi:10.1016/0022-1694(95)02922-2

Elderfield H, Greaves MJ (1982) The rare earth elements in seawater. Nature 296: 214-219. doi:10.1038/296214a0

Elderfield H, Upstill-Goddard R, Sholkovitz ER (1990) The rare earth elements in rivers, estuaries, and coastal seas and their significance to the composition of ocean waters. Geochim Cosmochim Acta 54: 971-991. doi:10.1016/0016-7037(90)90432-K

Gammons CH, Wood SA, Nimick DA (2005) Diel behavior of rare earth elements in a mountain stream with acidic to neutral pH. Geochim Cosmochim Acta 69: 3747-3758. doi:10.1016/j.gca.2005.03.019

Goldstein SJ, Jacobsen SB (1988) Rare earth elements in river waters. Earth Planet Sci Lett 89: 35-47. doi:10.1016/0012-821X(88)90031-3

Gosselin DC, Smith MR, Lepel EA, Laul JC (1992) Rare earth elements in chloride-rich groundwater, Palo Duro Basin, Texas, USA. Geochim Cosmochim Acta 56: 1495-1505. doi:10.1016/00167037(92)90219-9

Gruau G, Dia A, Olivié-Lauquet G, Davranche M, Pinay G (2004) Controls on the distribution of rare earth elements in shallow groundwaters. Water Res 38: 3576-3586. doi:10.1016/j.watres.2004.04.056

Hummel W, Berner U, Curti E, Pearson FJ, Thoenen T (2002) Nagra/PSI Chemical Thermodynamic Data Base 01/01. Universal Publishers/uPUBLISH.com, Parkland. 
Ingri J, Widerlund A, Land M, Gustafsson Ö, Andersson P, Öhlander B (2000) Temporal variations in the fractionation of the rare earth elements in a boreal river; the role of colloidal particles. Chem Geol 166: 23-45. doi:10.1016/S0009-2541(99)00178-3

Johannesson KH, Hendry MJ (2000) Rare earth element geochemistry of groundwaters from a thick till and clay-rich aquitard sequence, Saskatchewan, Canada. Geochim Cosmochim Acta 64: 14931509. doi:10.1016/S0016-7037(99)00402-0

Johannesson KH, Burdige DJ (2007) Balancing the global oceanic neodymium budget: Evaluating the role of groundwater. Earth Planet Sci Lett 253: 129-142. doi:10.1016/j.epsl.2006.10.021

Johannesson KH, Stetzenbach KJ, Hodge VF (1997) Rare earth elements as geochemical tracers of regional groundwater mixing. Geochim Cosmochim Acta 61: 3605-3618. doi:10.1016/S00167037(97)00177-4

Johannesson KH, Farnham IM, Guo C, Stetzenbach KJ (1999) Rare earth element fractionation and concentration variations along a groundwater flow path within a shallow, basin-fill aquifer, southern Nevada, USA. Geochim Cosmochim Acta 63: 2697-2708. doi:10.1016/S00167037(99)00184-2

Johannesson KH, Zhou X, Guo C, Stetzenbach KJ, Hodge VF (2000) Origin of rare earth element signatures in groundwaters of circumneutral $\mathrm{pH}$ from southern Nevada and eastern California, USA. Chem Geol 164: 239-257. doi:10.1016/S0009-2541(99)00152-7

Johannesson KH, Tang J, Daniels JM, Bounds WJ, Burdige DJ (2004) Rare earth element concentrations and speciation in organic-rich blackwaters of the Great Dismal Swamp, Virginia, USA. Chem Geol 209: 271-294. doi:10.1016/j.chemgeo.2004.06.012

Johannesson KH, Hawkins Jr. DL, Cortès A (2006) Do Archean chemical sediments record ancient seawater rare earth element patterns? Geochim Cosmochim Acta 70: 871-890. doi:10.1016/j.gca.2005.10.013

Klungness GD, Byrne RH (2000) Comparative hydrolysis behavior of the rare earths and yttrium: the influence of temperature and ionic strength. Polyhedron 19: 99-107. doi:10.1016/S02775387(99)00332-0

Koeppenkastrop D, De Carlo EH (1992) Sorption of rare-earth elements from seawater onto synthetic mineral particles: An experimental approach. Chem Geol 95: 251-263. doi:10.1016/00092541(92)90015-W 
Koeppenkastrop D, De Carlo EH (1993) Uptake of rare earth elements from solution by metal oxides. Environ Sci Technol 27: 1796-1802. doi:10.1021/es00046a006

Köhler SJ, Lidman F, Hassellöv M, Stolpe B, Mörth M, Björkvald L, Laudon H (2009) Temporal variations in the export of REE in boreal catchments of varying character and size. Geochim Cosmochim Acta 73 : A675. doi:10.1016/j.gca.2009.05.009

Lawrence MG, Greig A, Collerson KD, Kamber BS (2006) Rare earth element and yttrium variability in South East Queensland waterways. Aquat Geochem 12: 39-72. doi:10.1007/s10498-0054471-8

Leybourne MI, Johannesson KH (2008) Rare earth elements (REE) and yttrium in stream waters, stream sediments, and Fe-Mn oxyhydroxides: fractionation, speciation, and controls over REE + Y patterns in the surface environment. Geochim Cosmochim Acta 72: 5962-5983. doi:10.1016/j.gca.2008.09.022

Lofts S, Tipping E, Hamilton-Taylor J (2008) The chemical speciation of Fe(III) in freshwaters. Aquat Geochem 14: 337-358. doi:10.1007/s10498-008-9040-5

Luo Y-R, Byrne RH (2004) Carbonate complexation of yttrium and the rare earth elements in natural rivers. Geochim Cosmochim Acta 68: 691-699. doi:10.1016/S0016-7037(03)00495-2

Molénat J, Durand P, Gascuel-Odoux C, Davy P, Gruau G (2002) Mechanisms of nitrate transfer from soil to stream in an agricultural watershed of French Brittany. Water Air Soil Pollut 133: 161183. doi:10.1023/A:1012903626192

Molénat J, Gascuel-Odoux C, Ruiz L, Gruau G (2008) Role of water table dynamics on stream nitrate export and concentration in agricultural headwater catchment (France). J Hydrol 348: 363378. doi:10.1016/j.jhydrol.2007.10.005

Ohta A, Kawabe I (2001) REE(III) adsorption onto Mn dioxide and Fe oxyhydroxide: Ce(III) oxidation by Mn dioxide. Geochim Cosmochim Acta 65: 695-703. doi:10.1016/S0016-7037(00)00578-0

Olivié-Lauquet G, Gruau G, Dia A, Riou C, Jaffrezic A, Henin O (2001) Release of trace elements in wetlands: role of seasonal variability. Water Res 35: 943-952. doi:10.1016/S00431354(00)00328-6

Parkhurst DL, Appelo CAJ (1999) User's guide to PHREEQC (version 2) - A computer program for speciation, batch-reaction, one-dimensional transport, and inverse geochemical calculations. Water-Resources Investigations Report 99-4259, US Geological Survey, Denver 
Pauwels H, Kloppmann W, Foucher JC, Martelat A, Fritsche V (1998) Field tracer test for denitrification in a pyrite-bearing schist aquifer. Appl Geochem 13: 767-778. doi:10.1016/S0883-2927(98)00003-1

Pellerin J, Van Vliet-Lanoë B (1998) Le bassin du Coët-Dan au coeur du Massif armoricain. 2. Analyse cartographique de la région de Naizin. In: Cheverry C (ed) Agriculture Intensive et Qualité des Eaux, INRA, Paris, pp. 17-24.

Pokrovsky OS, Dupré B, Schott J (2005) Fe-Al-organic colloids control of trace elements in peat soil solutions: results of utlrafiltration and dialysis. Aquat Geochem 11: 241-278. doi:10.1007/s10498-004-4765-2

Pourret O, Davranche M, Gruau G, Dia A (2007a) Organic complexation of rare earth elements in natural waters: Evaluating model calculations from ultrafiltration data. Geochim Cosmochim Acta 71: 2718-2735. doi:10.1016/j.gca.2007.04.001

Pourret O, Dia A, Davranche M, Gruau G, Hénin O, Angée M (2007b) Organo-colloidal control on major- and trace-element partitioning in shallow groundwaters: confronting ultrafiltration and modelling. Appl Geochem 22: 1568-1582. doi:10.1016/j.apgeochem.2007.03.022

Pourret O, Davranche M, Gruau G, Dia A (2007c) Rare Earth Elements complexation with humic acid. Chem Geol 243: 128-141. doi:10.1016/j.chemgeo.2007.05.018

Pourret O, Davranche M, Gruau G, Dia A (2008) New insights into cerium anomalies in organic rich alkaline waters. Chem Geol 251: 120-127. doi:10.1016/j.chemgeo.2008.03.002

Schijf J, Byrne RH (2004) Determination of $\mathrm{SO}_{4} \beta_{1}$ for yttrium and the rare earth elements at $\mathrm{I}=0.66 \mathrm{~m}$ and $\mathrm{t}=25^{\circ} \mathrm{C}$-Implications for YREE solution speciation in sulfate-rich waters. Geochim Cosmochim Acta 68: 2825-2837. doi:10.1016/j.gca.2003.12.003

Sholkovitz ER (1995) The aquatic chemistry of rare earth elements in rivers and estuaries. Aquat Geochem 1: 1-34. doi:10.1007/BF01025229

Smedley PL (1991) The geochemistry of rare earth elements in groundwater from the Carnmenellis area, southwest England. Geochim Cosmochim Acta 55: 2767-2779. doi:10.1016/00167037(91)90443-9

Sonke JE, Salters VJM (2006) Lanthanide-humic substances complexation. I. Experimental evidence for a lanthanide contraction effect. Geochim Cosmochim Acta 70: 1495-1506. doi:10.1016/j.gca.2005.11.017 
Stern JC, Sonke JE, Salters VJM (2007) A capillary electrophoresis-ICP-MS study of rare earth element complexation by humic acids. Chem Geol 246: 170-180. doi:10.1016/j.chemgeo.2007.09.008

Tang J, Johannesson KH (2005) Adsorption of rare earth elements onto Carrizo sand: Experimental investigations and modeling with surface complexation. Geochim Cosmochim Acta 69: 52475261. doi:10.1016/j.gca.2005.06.021

Tanizaki Y, Shimokawa T, Nakamura M (1992) Physicochemical speciation of trace elements in river waters by size fractionation. Environ Sci Technol 26: 1433-1444. doi:10.1021/es00031a023

Taylor SR, McLennan SM (1985) The Continental Crust: Its composition and evolution. Blackwell, Oxford.

Thurman EM (1985) Organic Geochemistry of Natural Waters. Nijhoff/Junk, Dordrechtthe.

Tipping E (1998) Humic Ion-Binding Model VI: an improved description of the interactions of protons and metal ions with humic substances. Aquat Geochem 4: 3-48. doi:10.1023/A:1009627214459

Viers J, Dupré B, Polvé M, Schott J, Dandurand J-L, Braun JJ (1997) Chemical weathering in the drainage basin of a tropical watershed (Nsimi-Zoetele site, Cameroon): comparison between organic-poor and organic-rich waters. Chem Geol 140: 181-206. doi:10.1016/S00092541(97)00048-X

Welch SA, Christy AG, Isaacson L, Kirste D (2009) Mineralogical control of rare earth elements in acidic sulfate soils. Geochim Cosmochim Acta 73: 44-64. doi:10.1016/j.gca.2008.10.017

Yeghicheyan D, Carignan J, Valladon M, Bouhnik Le Coz M, Le Cornec F, Castrec-Rouelle M, Robert M, Aquilina L, Aubry E, Churlaud C, Dia A, Deberdt S, Dupré B, Freydier R, Gruau G, Hénin O, de Kersabiec A-M, Macé J, Marin L, Morin N, Petitjean P, Serrat E. (2001) Compilation of silicon and thirty one trace elements measured in the natural river water reference material SLRS-4 (NRC-CNRC). Geostandard Newslett 25: 465-474. doi:10.1111/j.1751908X.2001.tb00617.x 


\section{Table and figure captions}

Table 1 Average concentrations for Guériniec groundwaters. Major solute and REE are in $\mu g \mathrm{~L}^{-1}$. DOC and major anions $\left(\mathrm{Cl}^{-}, \mathrm{SO}_{4}{ }^{2-}, \mathrm{NO}_{3}{ }^{-}\right)$are in $\mathrm{mg} \mathrm{L}^{-1}$. Alkalinity data are in $\mu \mathrm{mol} \mathrm{L}^{-1}$. The amplitude of the Ce anomaly was calculated as follows $\mathrm{Ce} / \mathrm{Ce}{ }^{*}=2 * \mathrm{Ce}_{\mathrm{UCC}} /\left(\mathrm{La}_{\mathrm{UCC}}+\mathrm{Pr}_{\mathrm{UCC}}\right)$

Table 2 Ultrafiltration results for PG3 and PG4 samples (November 2004). Major solute and REE are in $\mu \mathrm{g} \mathrm{\textrm {L } ^ { - 1 }}$. DOC and major anions $\left(\mathrm{Cl}^{-}, \mathrm{SO}_{4}{ }^{2-}, \mathrm{NO}_{3}{ }^{-}\right)$are in $\mathrm{mg} \mathrm{L}^{-1}$. Alkalinity data are in $\mu \mathrm{mol} \mathrm{L}{ }^{-1}$

Table 3 Speciation results obtained using Model VI for PG3, PG4 and PG5 groundwaters sampled in May and November 2004

Table A1 Model VI parameters for HA and FA (Tipping 1998)

Fig. 1 Location map of the Kervidy/Coët-Dan catchment (Brittany, France) showing the Guériniec transect and the groundwater sampling wells setup along this transect. Average groundwater levels for wet (winter) and dry (summer) periods are shown for comparison. Scheme conceptualizing the hydrochemical behavior of the Guériniec transect is adapted from Dia et al. (2000) and Molénat et al. (2002). Black arrows correspond to nitrate-rich fluxes, whereas white arrows correspond to nitrate-poor fluxes. The small black arrows on nitrate and sulfate white boxes correspond to increasing or decreasing contents. Shaded areas located close to the channel network on the catchment map indicate the location of wetland zones. The Mercy area corresponds to the wetland zone where DOC-rich, shallow $(<0.5 \mathrm{~m})$ groundwaters from piezometers PF1 and PF3 were investigated for major and trace elements including REE geochemistry by Pourret et al. (2007a, b)

Fig. 2 Diagrams illustrating systematic variation of the chemistry of Guériniec groundwater depending on the topographic position of sampling wells. Presented values are average values calculated by pooling chemical analyses collected during the seven-year monitoring period. Error bars correspond to relative standard deviations (data are displayed in Table 1) 
Fig. 3 Sketch diagram showing downslope evolution of Upper Continental Crust (UCC)-normalized REE profiles in groundwaters from the Guériniec transect (UCC values are from Taylor and McLennan 1985). Many PG1 well samples have middle and heavy REE concentrations close to or below the

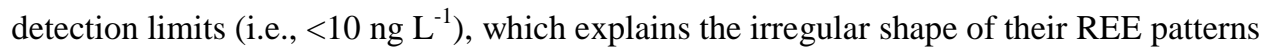

Fig. 4 Temporal monitoring of (a) LREE/HREE) UCC ratios and (b) negative Ce anomaly amplitude in Guériniec groundwater samples

Fig. 5 UCC-normalized REE patterns after successive ultrafiltration (i.e., $0.2 \mu \mathrm{m}, 30 \mathrm{kDa}, 10 \mathrm{kDa}$ and $5 \mathrm{kDa}$ ) of groundwaters from (a) PG3 and (b) PG4 wells. Error bars correspond to standard deviations obtained from duplicate measurements, with some error bars being smaller than the symbol size (data are displayed in Table 2)

Fig. 6 (a) $\mathrm{SO}_{4}{ }^{2-}$ concentrations (mg L ${ }^{-1}$ ) and (b) $\Sigma \mathrm{REE}$ concentrations $\left(\mu \mathrm{g} \mathrm{L}^{-1}\right)$ as a function of $\mathrm{NO}_{3}{ }^{-}$ concentrations (mg L ${ }^{-1}$ ) for the six studied wells. Solid lines represent (a) linear regression between $\mathrm{SO}_{4}{ }^{2-}$ and $\mathrm{NO}_{3}{ }^{-}$and (b) the mixing line between PG6 and PG1

Fig. $7 \mathrm{pH}$ as a function of $\Sigma$ REE concentrations $\left(\mu \mathrm{g} \mathrm{L}{ }^{-1}\right)$ for the six studied wells, solid line represents linear regression

Fig. 8 (a) Modeled $\Sigma$ REE concentrations $\left(\mu \mathrm{g} \mathrm{L}^{-1}\right)$ as a function of measured $\Sigma$ REE concentrations ( $\mu \mathrm{g}$ $\mathrm{L}^{-1}$ ) and corresponding (b) modeled Ce/Ce* as a function of measured $\mathrm{Ce} / \mathrm{Ce} *$ for the six studied wells. Solid line represents the 1:1 line

Fig. 9 LREE concentrations ( $\mu \mathrm{g} \mathrm{L}^{-1}$ ) as compared to DOC concentrations (mg $\mathrm{L}^{-1}$ ) for (a) PG1, (b) PG2, (c) PG3, (d) PG4, (e) PG5 and (f) PG6 samples, respectively. Solid lines represent linear regression when applicable 
Fig. 10 (a) DOC concentrations (mg L $\left.{ }^{-1}\right)$ and (b) $\left(\mathrm{Ce} / \mathrm{Ce}^{*}\right)$ ratio evolution from February 2006 to June 2007 both represented by full black circles, as compared to the water table depth (m), represented by solid line, in PG3

Fig. $11 \mathrm{Ce} / \mathrm{Ce}$ * ratios evolution as a function of $\mathrm{NO}_{3}{ }^{-}$concentrations $\left(\mathrm{mg} \mathrm{L}^{-1}\right)$ illustrating the inorganic groundwater mixing (i.e., solid lines) for various $\mathrm{pH}$ (i.e., 5.6, 5.8 and 6.2) and the corresponding colloidal addition (materialized by black vertical arrows) necessary to fit the measured $\mathrm{Ce} / \mathrm{Ce}$ * in PG2, PG3, PG4 and PG5 groundwater samples. Gray and white rectangles represent the colloidal addition if considering PF1 and PF3, respectively

Fig. 12 Sketch diagram illustrating the presence of three-groundwater flow paths in the Kervidy/CoëtDan aquifer

Fig. $13 \mathrm{Ce} / \mathrm{Ce}^{*}$ ratios as a function to distance from stream (m). Data for Goyoum and Le Home toposequences are from Braun et al. (1998) and Gruau et al. (2004), respectively 
Table 1.

\begin{tabular}{|c|c|c|c|c|c|c|c|c|c|c|c|c|}
\hline \multirow[t]{2}{*}{ Well No } & \multirow{2}{*}{$\begin{array}{l}\text { PG1 } \\
\text { mean }\end{array}$} & \multicolumn{3}{|c|}{ PG2 } & \multirow{2}{*}{$\begin{array}{l}\text { PG3 } \\
\text { mean }\end{array}$} & \multicolumn{3}{|c|}{ PG4 } & \multirow{2}{*}{$\begin{array}{l}\text { PG5 } \\
\text { mean }\end{array}$} & \multicolumn{3}{|c|}{ PG6 } \\
\hline & & r.s.d. & mean & r.s.d & & r.s.d & mean & r.s.d & & r.s.d & mean & r.s.d \\
\hline $\mathrm{pH}$ & 6.6 & 0.2 & 6.2 & 0.3 & 5.8 & 0.4 & 5.7 & 0.4 & 5.9 & 0.6 & 5.8 & 0.4 \\
\hline Eh & 406 & 94 & 471 & 45 & 465 & 43 & 465 & 45 & 414 & 91 & 484 & 24 \\
\hline Temperature & 12.6 & 2.9 & 12.2 & 3.4 & 12.2 & 3.6 & 12.5 & 3.3 & 12.8 & 3.2 & 10.5 & 3.1 \\
\hline Conductivity & 204 & 19 & 227 & 17 & 244 & 33 & 286 & 39 & 285 & 33 & 341 & 126 \\
\hline $\mathrm{Cl}^{-}$ & 16.06 & 0.75 & 26.87 & 1.47 & 31.56 & 2.24 & 32.84 & 2.01 & 28.14 & 1.27 & 28.18 & 3.13 \\
\hline $\mathrm{SO}_{4}^{2-}$ & 15.68 & 0.45 & 6.96 & 1.10 & 4.88 & 1.57 & 5.30 & 2.98 & 1.63 & 0.53 & 2.51 & 0.89 \\
\hline $\mathrm{NO}_{3}{ }^{-}$ & 0.76 & 0.87 & 41.60 & 4.04 & 63.78 & 13.06 & 91.97 & 9.13 & 97.16 & 6.29 & 104.45 & 15.03 \\
\hline Alkalinity & 2,491 & 1,768 & 660 & 84 & 347 & 207 & 193 & 117 & 200 & 141 & 2,491 & 1,768 \\
\hline DOC & 1.05 & 0.90 & 0.87 & 0.68 & 2.73 & 2.15 & 1.28 & 0.74 & 0.53 & 0.14 & n.a. & n.a. \\
\hline $\mathrm{Na}$ & 19,247 & 1,488 & 18,461 & 1,500 & 18,287 & 1,273 & 18,855 & 1,782 & 15,545 & 1,198 & 16,867 & 1,158 \\
\hline K & 613 & 119 & 534 & 53 & 1,140 & 479 & 2,629 & 1,062 & 1,030 & 133 & 2,712 & 806 \\
\hline $\mathrm{Ca}$ & 5,927 & 250 & 6,768 & 333 & 7,431 & 1,362 & 9,580 & 2,671 & 7,060 & 395 & 18,561 & 1,659 \\
\hline $\mathrm{Mg}$ & 10,308 & 930 & 11,690 & 1,124 & 13,208 & 1,348 & 15,578 & 1,951 & 17,869 & 1,200 & 14,654 & 2,591 \\
\hline $\mathrm{Mn}$ & 317.80 & 117.89 & 6.10 & 17.88 & 15.54 & 7.59 & 46.02 & 85.64 & 9.97 & 2.73 & 44.9 & 24.8 \\
\hline $\mathrm{Fe}$ & 95.50 & 313.58 & 10.07 & 11.03 & 32.13 & 33.06 & 15.62 & 8.83 & 12.14 & 9.57 & 33.7 & 26.8 \\
\hline $\mathrm{La}$ & 0.0056 & 0.0065 & 0.0257 & 0.0236 & 1.1505 & 1.0308 & 2.1090 & 1.0126 & 2.0020 & 0.4930 & 6.1794 & 4.2460 \\
\hline $\mathrm{Ce}$ & 0.0087 & 0.0065 & 0.0297 & 0.0297 & 1.6947 & 1.4973 & 1.3966 & 0.9040 & 0.2095 & 0.0535 & 2.1466 & 1.5822 \\
\hline Pr & 0.0014 & 0.0018 & 0.0092 & 0.0095 & 0.3587 & 0.3157 & 0.7243 & 0.4580 & 0.5142 & 0.1404 & 1.4181 & 0.8162 \\
\hline $\mathrm{Nd}$ & 0.0071 & 0.0075 & 0.0495 & 0.0500 & 1.6018 & 1.3897 & 3.1060 & 2.0403 & 2.0524 & 0.5757 & 5.4842 & 3.0260 \\
\hline Sm & 0.0015 & 0.0013 & 0.0147 & 0.0152 & 0.3216 & 0.2748 & 0.6494 & 0.4345 & 0.3708 & 0.1119 & 0.8890 & 0.4795 \\
\hline $\mathrm{Eu}$ & 0.0003 & 0.0005 & 0.0035 & 0.0037 & 0.0690 & 0.0571 & 0.1342 & 0.0867 & 0.0712 & 0.0221 & 0.1523 & 0.0863 \\
\hline $\mathrm{Gd}$ & 0.0013 & 0.0012 & 0.0178 & 0.0190 & 0.2985 & 0.2480 & 0.4516 & 0.2736 & 0.2458 & 0.0717 & 0.5327 & 0.3161 \\
\hline $\mathrm{Tb}$ & 0.0001 & 0.0003 & 0.0018 & 0.0020 & 0.0300 & 0.0250 & 0.0507 & 0.0297 & 0.0235 & 0.0070 & 0.0500 & 0.0317 \\
\hline Dy & 0.0009 & 0.0008 & 0.0095 & 0.0099 & 0.1475 & 0.1191 & 0.2652 & 0.1527 & 0.1086 & 0.0313 & 0.2256 & 0.1465 \\
\hline Ho & 0.0001 & 0.0003 & 0.0019 & 0.0020 & 0.0295 & 0.0235 & 0.0505 & 0.0293 & 0.0194 & 0.0053 & 0.0406 & 0.0261 \\
\hline Er & 0.0004 & 0.0006 & 0.0058 & 0.0054 & 0.0830 & 0.0641 & 0.1413 & 0.0821 & 0.0537 & 0.0152 & 0.1129 & 0.0694 \\
\hline $\mathrm{Tm}$ & 0.0000 & 0.0003 & 0.0007 & 0.0008 & 0.0108 & 0.0083 & 0.0187 & 0.0112 & 0.0067 & 0.0019 & 0.0144 & 0.0088 \\
\hline $\mathrm{Yb}$ & 0.0004 & 0.0005 & 0.0045 & 0.0043 & 0.0679 & 0.0512 & 0.1145 & 0.0696 & 0.0401 & 0.0119 & 0.0867 & 0.0500 \\
\hline $\mathrm{Lu}$ & 0.0001 & 0.0003 & 0.0008 & 0.0008 & 0.0135 & 0.0098 & 0.0189 & 0.0116 & 0.0067 & 0.0020 & 0.0151 & 0.0085 \\
\hline$\Sigma \mathrm{REE}$ & 0.0279 & 0.0255 & 0.1751 & 0.1747 & 5.8769 & 5.1097 & 9.2309 & 5.5458 & 5.7245 & 1.5325 & 17.3477 & 10.7038 \\
\hline $\mathrm{Ce} / \mathrm{Ce}^{*}$ & 0.77 & 0.30 & 0.42 & 0.05 & 0.59 & 0.04 & 0.26 & 0.08 & 0.05 & 0.01 & 0.15 & 0.03 \\
\hline (LREE/HREE) $)_{\text {UCC }}$ & 1.14 & 0.78 & 0.91 & 0.13 & 1.45 & 0.12 & 1.60 & 0.09 & 2.57 & 0.05 & 3.22 & 0.23 \\
\hline
\end{tabular}


Table 2

\begin{tabular}{|c|c|c|c|c|c|c|c|c|c|c|c|c|c|c|}
\hline Well $N^{\circ}$ & & & & PG3 & & & & & & & PG4 & & & \\
\hline & $\begin{array}{l}0.2 \\
\mu \mathrm{m}\end{array}$ & $\begin{array}{c}30 \\
\mathrm{kDa}\end{array}$ & $\begin{array}{c}30 \\
\mathrm{kDa}\end{array}$ & $\begin{array}{c}10 \\
\mathrm{kDa}\end{array}$ & $\begin{array}{c}10 \\
\mathrm{kDa}\end{array}$ & $5 \mathrm{kDa}$ & $5 \mathrm{kDa}$ & $\begin{array}{l}0.2 \\
\mu \mathrm{m}\end{array}$ & $\begin{array}{c}30 \\
\mathrm{kDa}\end{array}$ & $\begin{array}{c}30 \\
\mathrm{kDa}\end{array}$ & $\begin{array}{c}10 \\
\mathrm{kDa}\end{array}$ & $\begin{array}{c}10 \\
\mathrm{kDa}\end{array}$ & 5 kDa & $5 \mathrm{kDa}$ \\
\hline $\mathrm{pH}$ & 6.7 & & & & & & & 6.1 & & & & & & \\
\hline $\mathrm{Cl}^{-}$ & 31.09 & & & & & & & 30.88 & & & & & & \\
\hline $\mathrm{SO}_{4}{ }^{2-}$ & 5.75 & & & & & & & 6.57 & & & & & & \\
\hline $\mathrm{NO}_{3}^{-}$ & 55.95 & & & & & & & 80.59 & & & & & & \\
\hline $\begin{array}{c}\text { Alkalinit } \\
\mathrm{y}\end{array}$ & 493 & & & & & & & 275 & & & & & & \\
\hline DOC & 4.34 & 4.19 & 4.16 & 4.02 & 3.96 & 3.00 & 3.07 & 2.02 & 1.93 & 1.93 & 1.93 & 1.92 & 1.47 & 1.44 \\
\hline $\mathrm{Na}$ & 20580 & 20600 & 20410 & 20990 & 20750 & 15930 & 18790 & 16970 & 17540 & 17060 & 16190 & 15740 & 17489 & 16698 \\
\hline $\mathrm{K}$ & 1125 & 1160 & 1137 & 1173 & 1133 & 961 & 1081 & 3138 & 3141 & 3103 & 3000 & 2942 & 3177 & 3102 \\
\hline $\mathrm{Ca}$ & 7414 & 7499 & 7395 & 7623 & 7838 & 6501 & 7221 & 10210 & 10390 & 10210 & 9884 & 9779 & 10454 & 10298 \\
\hline Mg & 13160 & 13320 & 13150 & 13380 & 13230 & 10302 & 12382 & 13470 & 13670 & 13470 & 12980 & 12670 & 13630 & 12975 \\
\hline Mn & 5.93 & 5.95 & 5.88 & 6.03 & 5.75 & 1.57 & 1.72 & 33.31 & 33.53 & 33.05 & 32.32 & 32.36 & 34.17 & 33.75 \\
\hline $\mathrm{Fe}$ & 18.34 & 3.70 & 2.78 & 2.47 & 3.21 & b.d.l. & b.d.l. & 12.13 & 4.07 & 2.42 & b.d.l. & 0.50 & b.d.l. & 0.44 \\
\hline $\mathrm{La}$ & 0.7870 & 0.6070 & 0.6040 & 0.4790 & 0.4470 & $\begin{array}{c}0.335 \\
9\end{array}$ & $\begin{array}{c}0.385 \\
1\end{array}$ & 1.5470 & 1.5090 & 1.5000 & 1.3700 & 1.4120 & $\begin{array}{c}1.232 \\
6\end{array}$ & $\begin{array}{c}1.273 \\
5\end{array}$ \\
\hline $\mathrm{Ce}$ & 1.1810 & 0.9020 & 0.9010 & 0.6970 & 0.6550 & $\begin{array}{c}0.368 \\
3\end{array}$ & $\begin{array}{c}0.423 \\
3\end{array}$ & 0.8180 & 0.7920 & 0.7800 & 0.7160 & 0.7300 & $\begin{array}{c}0.633 \\
9\end{array}$ & $\begin{array}{c}0.661 \\
3\end{array}$ \\
\hline $\operatorname{Pr}$ & 0.2620 & 0.2040 & 0.2040 & 0.1600 & 0.1480 & $\begin{array}{c}0.119 \\
9\end{array}$ & $\begin{array}{c}0.134 \\
7\end{array}$ & 0.5490 & 0.5230 & 0.5240 & 0.4720 & 0.4830 & $\begin{array}{c}0.423 \\
3\end{array}$ & $\begin{array}{c}0.441 \\
2\end{array}$ \\
\hline $\mathrm{Nd}$ & 1.2350 & 0.9630 & 0.9650 & 0.7830 & 0.7120 & $\begin{array}{c}0.576 \\
7\end{array}$ & $\begin{array}{c}0.649 \\
3\end{array}$ & 2.4360 & 2.3270 & 2.2960 & 2.0810 & 2.1500 & $\begin{array}{c}1.878 \\
2\end{array}$ & $\begin{array}{c}1.965 \\
0\end{array}$ \\
\hline Sm & 0.2290 & 0.1840 & 0.1850 & 0.1350 & 0.1230 & $\begin{array}{c}0.102 \\
2\end{array}$ & $\begin{array}{c}0.121 \\
0\end{array}$ & 0.5150 & 0.4750 & 0.4770 & 0.4190 & 0.4360 & $\begin{array}{c}0.372 \\
0\end{array}$ & $\begin{array}{c}0.396 \\
3\end{array}$ \\
\hline $\mathrm{Eu}$ & 0.0478 & 0.0364 & 0.0362 & 0.0269 & 0.0249 & $\begin{array}{c}0.021 \\
1\end{array}$ & $\begin{array}{c}0.024 \\
0\end{array}$ & 0.1020 & 0.0945 & 0.0966 & 0.0850 & 0.0885 & $\begin{array}{c}0.077 \\
3\end{array}$ & $\begin{array}{c}0.079 \\
4\end{array}$ \\
\hline Gd & 0.2210 & 0.1680 & 0.1660 & 0.1200 & 0.1040 & $\begin{array}{c}0.098 \\
3\end{array}$ & $\begin{array}{c}0.108 \\
2\end{array}$ & 0.3370 & 0.3240 & 0.3200 & 0.2830 & 0.2920 & $\begin{array}{c}0.253 \\
4\end{array}$ & $\begin{array}{c}0.262 \\
8\end{array}$ \\
\hline $\mathrm{Tb}$ & 0.0209 & 0.0157 & 0.0160 & 0.0103 & 0.0093 & $\begin{array}{c}0.008 \\
5\end{array}$ & $\begin{array}{c}0.009 \\
5\end{array}$ & 0.0372 & 0.0340 & 0.0335 & 0.0295 & 0.0304 & $\begin{array}{c}0.026 \\
0\end{array}$ & $\begin{array}{c}0.027 \\
5\end{array}$ \\
\hline Dy & 0.1020 & 0.0762 & 0.0721 & 0.0525 & 0.0472 & $\begin{array}{c}0.043 \\
6\end{array}$ & $\begin{array}{c}0.047 \\
9\end{array}$ & 0.1860 & 0.1780 & 0.1760 & 0.1580 & 0.1590 & $\begin{array}{c}0.142 \\
2\end{array}$ & $\begin{array}{c}0.141 \\
8\end{array}$ \\
\hline Но & 0.0223 & 0.0164 & 0.0170 & 0.0122 & 0.0107 & $\begin{array}{c}0.009 \\
2\end{array}$ & $\begin{array}{c}0.010 \\
7\end{array}$ & 0.0378 & 0.0350 & 0.0351 & 0.0310 & 0.0326 & $\begin{array}{c}0.028 \\
7\end{array}$ & $\begin{array}{c}0.029 \\
4\end{array}$ \\
\hline Er & 0.0649 & 0.0506 & 0.0494 & 0.0362 & 0.0316 & $\begin{array}{c}0.029 \\
2\end{array}$ & $\begin{array}{c}0.032 \\
1\end{array}$ & 0.1070 & 0.1020 & 0.1040 & 0.0908 & 0.0941 & $\begin{array}{c}0.083 \\
7\end{array}$ & $\begin{array}{c}0.086 \\
0\end{array}$ \\
\hline $\mathrm{Tm}$ & 0.0089 & 0.0067 & 0.0062 & 0.0051 & 0.0046 & $\begin{array}{c}0.003 \\
7\end{array}$ & $\begin{array}{c}0.004 \\
0\end{array}$ & 0.0154 & 0.0140 & 0.0143 & 0.0118 & 0.0132 & $\begin{array}{c}0.011 \\
3\end{array}$ & $\begin{array}{c}0.011 \\
8\end{array}$ \\
\hline $\mathrm{Yb}$ & 0.0533 & 0.0432 & 0.0426 & 0.0306 & 0.0303 & $\begin{array}{c}0.026 \\
2\end{array}$ & $\begin{array}{c}0.027 \\
3\end{array}$ & 0.0954 & 0.0875 & 0.0863 & 0.0776 & 0.0796 & $\begin{array}{c}0.075 \\
3\end{array}$ & $\begin{array}{c}0.076 \\
4\end{array}$ \\
\hline $\mathrm{Lu}$ & 0.0108 & 0.0093 & 0.0088 & 0.0068 & 0.0062 & $\begin{array}{c}0.005 \\
5\end{array}$ & $\begin{array}{c}0.006 \\
0\end{array}$ & 0.0168 & 0.0154 & 0.0154 & 0.0135 & 0.0142 & $\begin{array}{c}0.013 \\
2\end{array}$ & $\begin{array}{c}0.013 \\
5\end{array}$ \\
\hline$\Sigma \mathrm{REE}$ & 4.2459 & 3.2825 & 3.2732 & 2.5546 & 2.3539 & $\begin{array}{c}1.748 \\
2\end{array}$ & $\begin{array}{c}1.983 \\
4\end{array}$ & 6.7996 & 6.5104 & 6.4581 & 5.8382 & 6.0145 & $\begin{array}{c}5.251 \\
0\end{array}$ & $\begin{array}{c}5.466 \\
1\end{array}$ \\
\hline $\mathrm{Ce} / \mathrm{Ce}^{*}$ & 0.58 & 0.58 & 0.58 & 0.57 & 0.57 & 0.41 & 0.42 & 0.20 & 0.20 & 0.20 & 0.20 & 0.20 & 0.20 & 0.20 \\
\hline
\end{tabular}

b.d.l. (below detection limit) 
Table 3

\begin{tabular}{llrrrr}
\hline & \% of species & $\mathrm{La}^{3+}$ & $\mathrm{LaSO}_{4}{ }^{+}$ & La-HM & other species \\
\hline PG3 & May & 7.0 & 0.5 & 92.5 & 0.0 \\
& Nov & 0.0 & 0.0 & 100.0 & 0.0 \\
PG4 & May & 67.0 & 6.0 & 26.1 & 0.9 \\
& Nov & 49.0 & 7.1 & 43.1 & 0.8 \\
& May & 74.0 & 2.5 & 22.2 & 1.2 \\
\\
\end{tabular}


Table A1.

\begin{tabular}{|c|c|c|}
\hline Parameter & Description & Values \\
\hline $\mathbf{n}_{\mathrm{A}}$ & Amount of type-A sites $\left(\mathrm{mol} \mathrm{g}^{-1}\right)$ & $4.8 \times 10^{-3}(\mathrm{FA}) .3 .3 \times 10^{-3}(\mathrm{HA})$ \\
\hline $\mathbf{n}_{\mathbf{B}}$ & Amount of type-B sites $\left(\mathrm{mol} \mathrm{g}^{-1}\right)$ & $0.5 \times \mathbf{n}_{A}$ \\
\hline $\mathbf{p K}_{\mathrm{A}}$ & Intrinsic proton dissociation constant for type-A sites & 3.2 (FA). 4.1 (HA) \\
\hline $\mathbf{p K}_{\mathrm{B}}$ & Intrinsic proton dissociation constant for type-B sites & 9.4 (FA). 8.8 (HA) \\
\hline$\Delta \mathrm{pK}_{\mathrm{A}}$ & Distribution term that modifies $\mathbf{p K}_{\mathrm{A}}$ & 3.3 (FA). 2.1 (HA) \\
\hline$\Delta \mathrm{pK}_{\mathrm{B}}$ & Distribution term that modifies $\mathrm{pK}_{\mathrm{B}}$ & 4.9 (FA). 3.6 (HA) \\
\hline $\log K_{M A}$ & Intrinsic equilibrium constant for metal binding at type-A sites & From experimental data ${ }^{a}$ \\
\hline $\log K_{M B}$ & Intrinsic equilibrium constant for metal binding at type-B sites & $3.39 \log K_{\mathrm{MA}}-1.15$ \\
\hline$\Delta \mathbf{L} \mathbf{K}_{1}$ & Distribution term that modifies $\log \mathrm{K}_{\mathrm{MA}}$ & 2.8 (REE) \\
\hline$\Delta \mathbf{L} \mathbf{K}_{2}$ & $\begin{array}{l}\text { Distribution term that modifies the strength of bidentate and tridentate } \\
\text { sites }\end{array}$ & $0.55 \log \mathrm{K}_{\mathrm{NH} 3}=0.29(\mathrm{REE})$ \\
\hline $\mathbf{P}$ & Electrostatic parameter & -115 (FA). -330 (HA) \\
\hline $\mathbf{K}_{\text {sel }}$ & Selectivity coefficient for counterion accumulation & 1 \\
\hline $\mathbf{M}$ & Molecular weight (kDa) & 1.5 (FA). 15 (HA) \\
\hline $\mathbf{r}$ & Molecular radius (nm) & 0.8 (FA). 1.72 (HA) \\
\hline
\end{tabular}

${ }^{\mathrm{a}}$ Pourret et al. (2007c) 


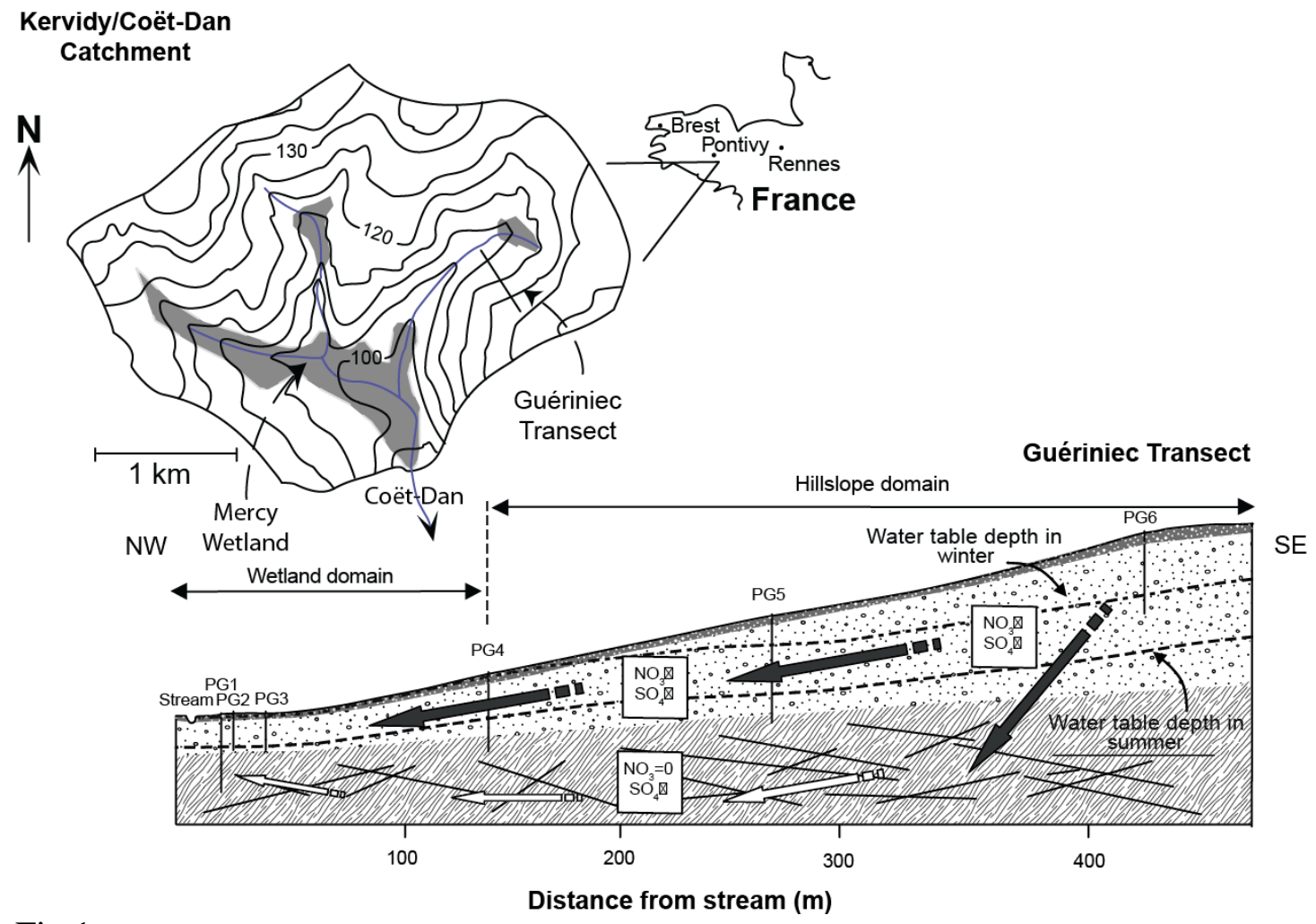

Fig.1 

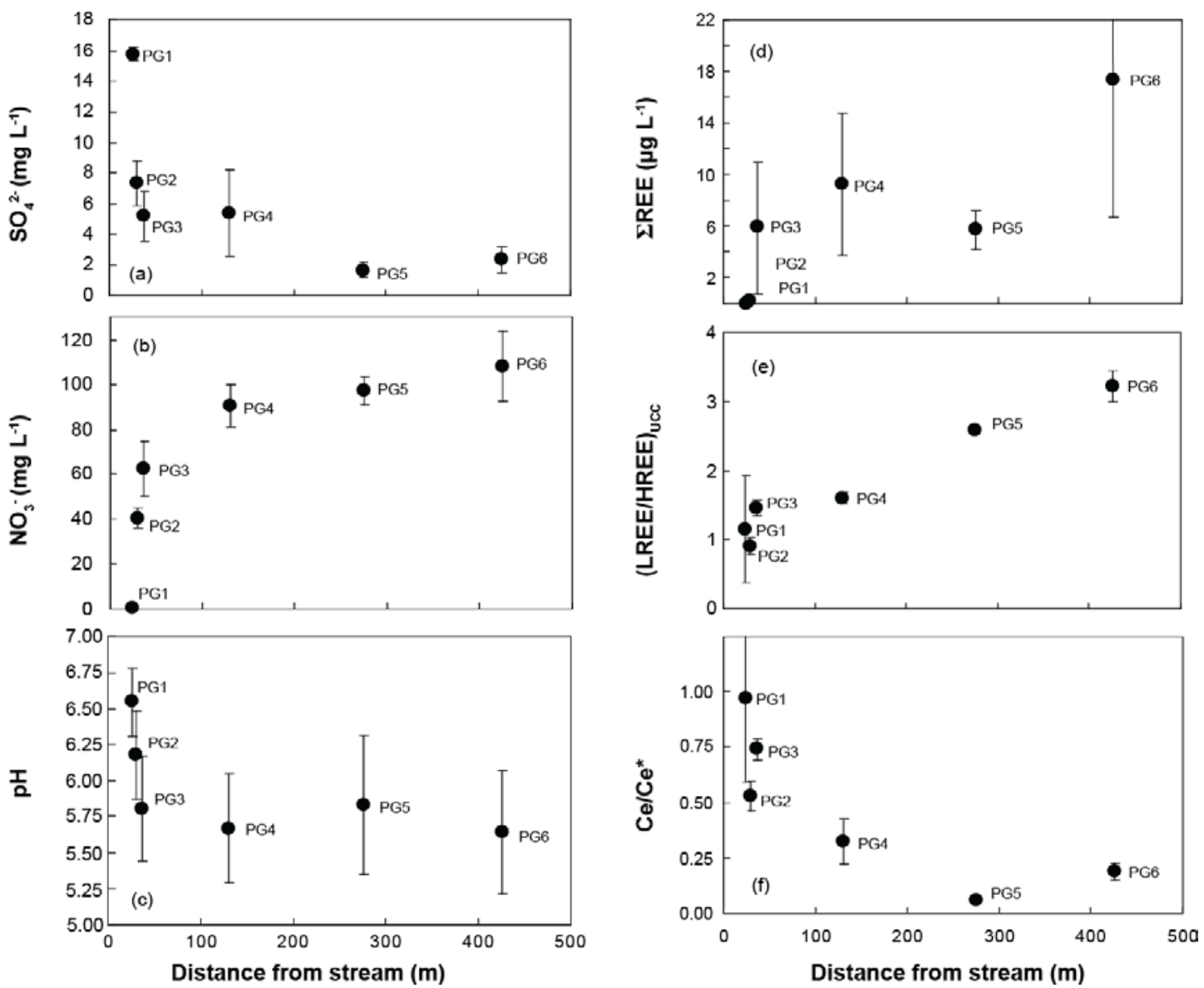

Fig.2 


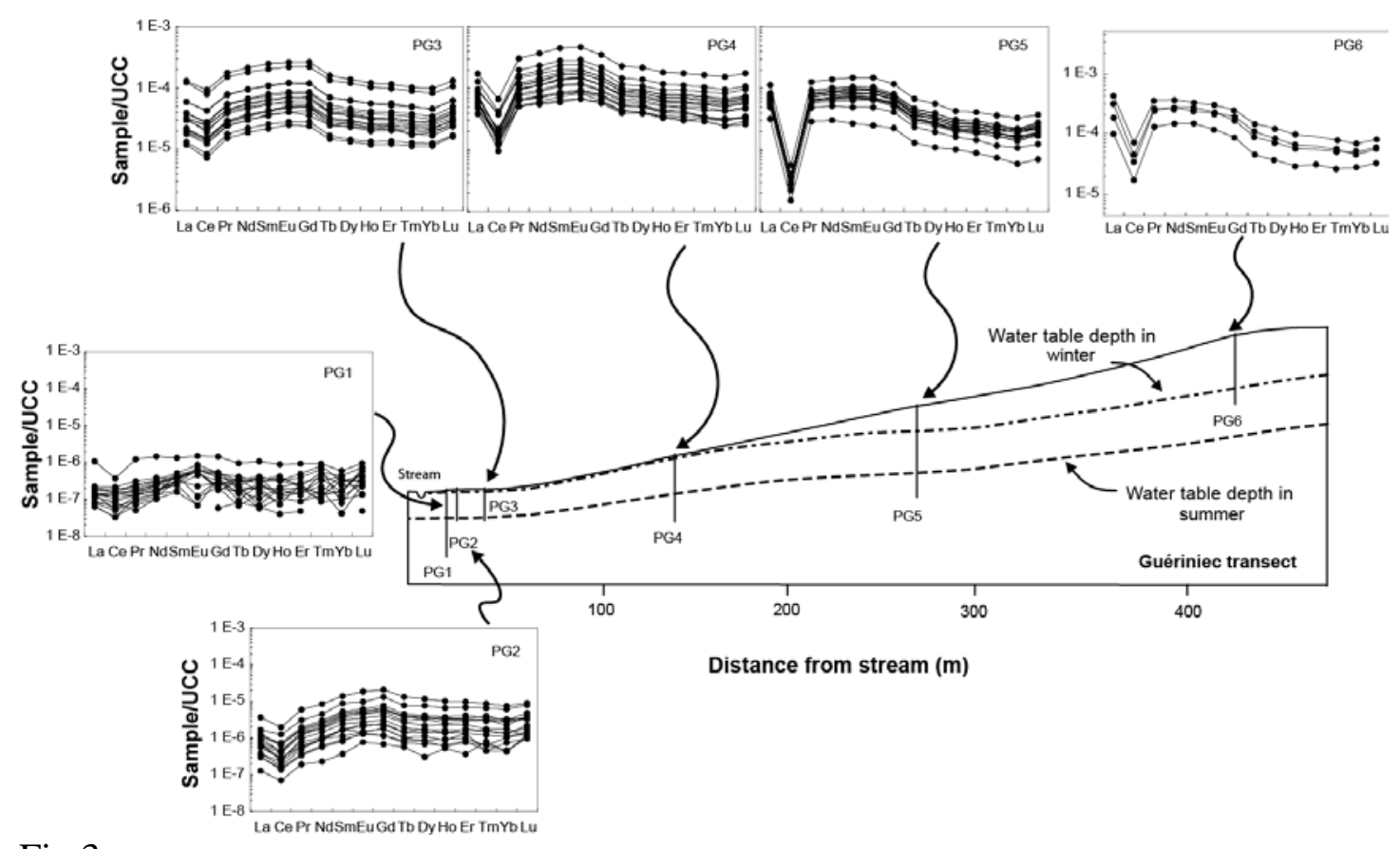

Fig.3 

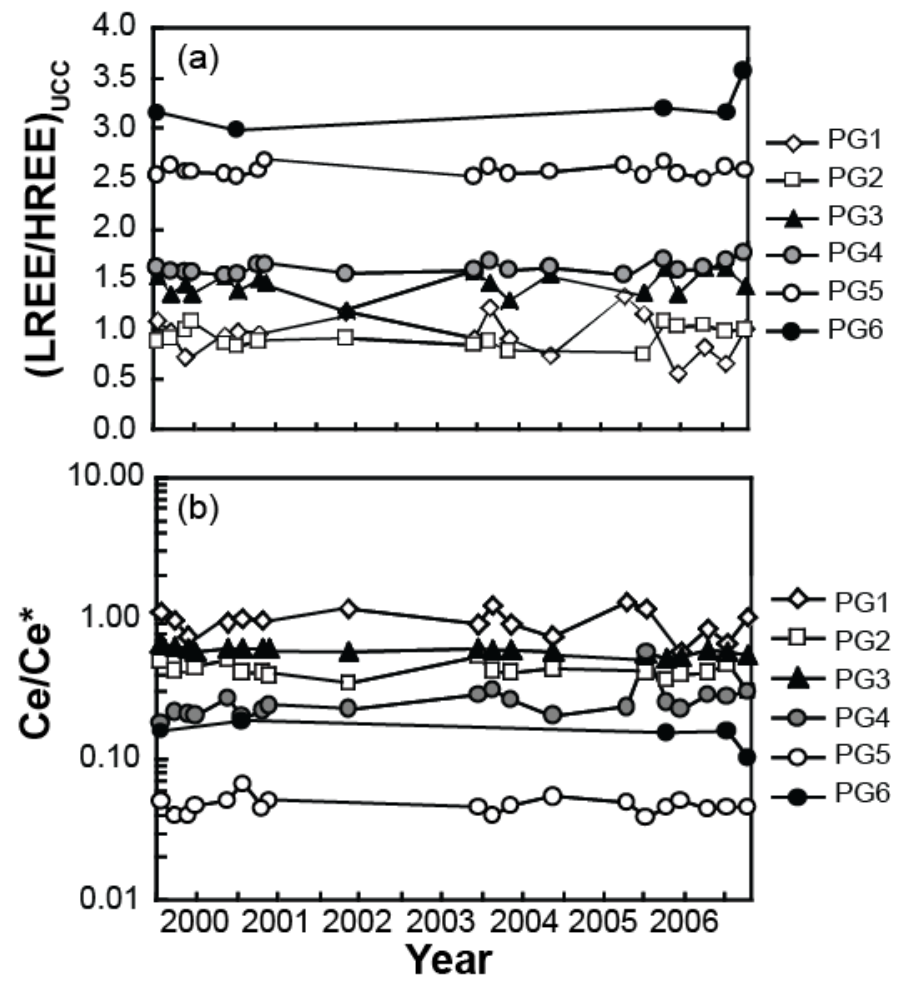

Fig.4 

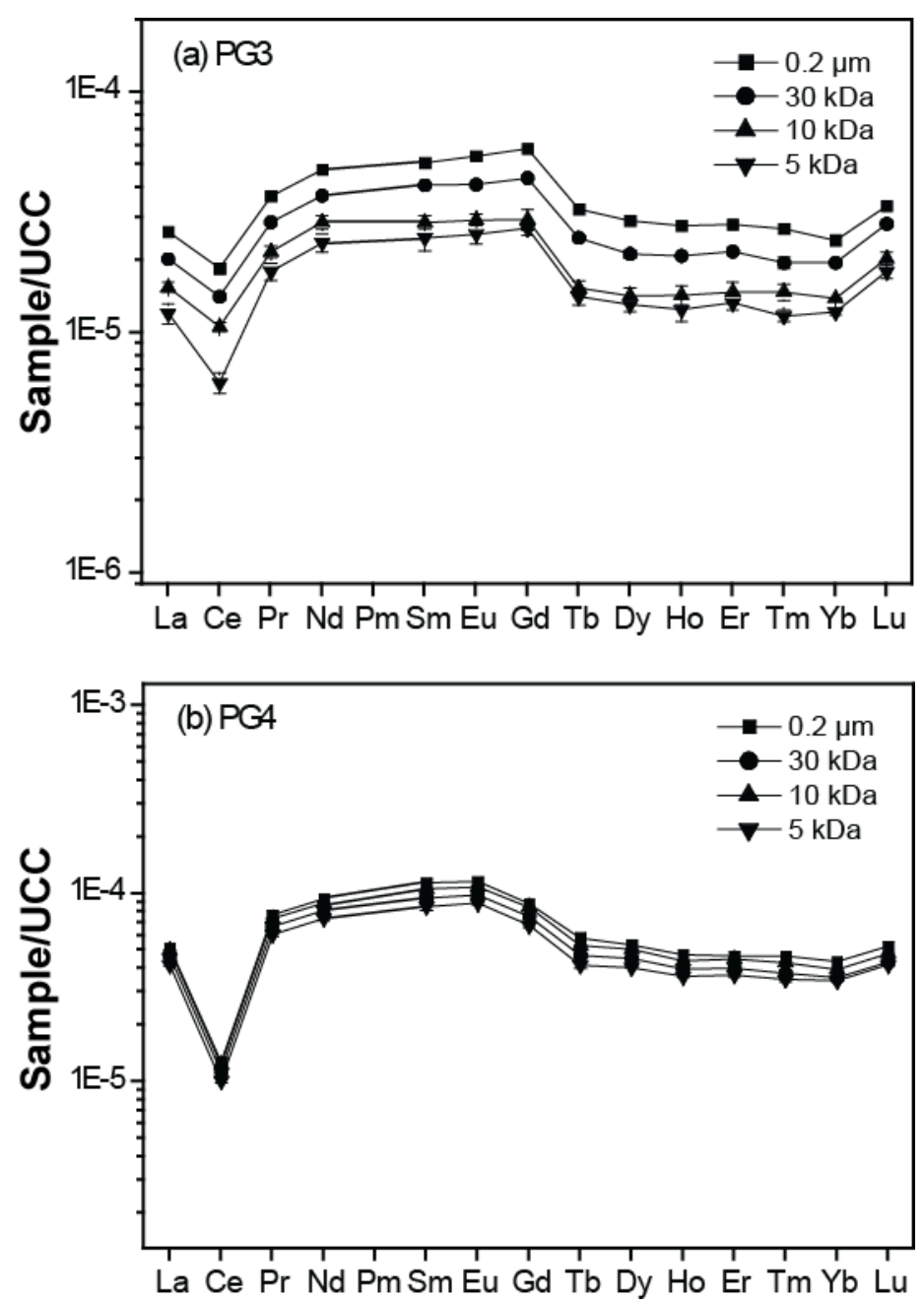

Fig.5 

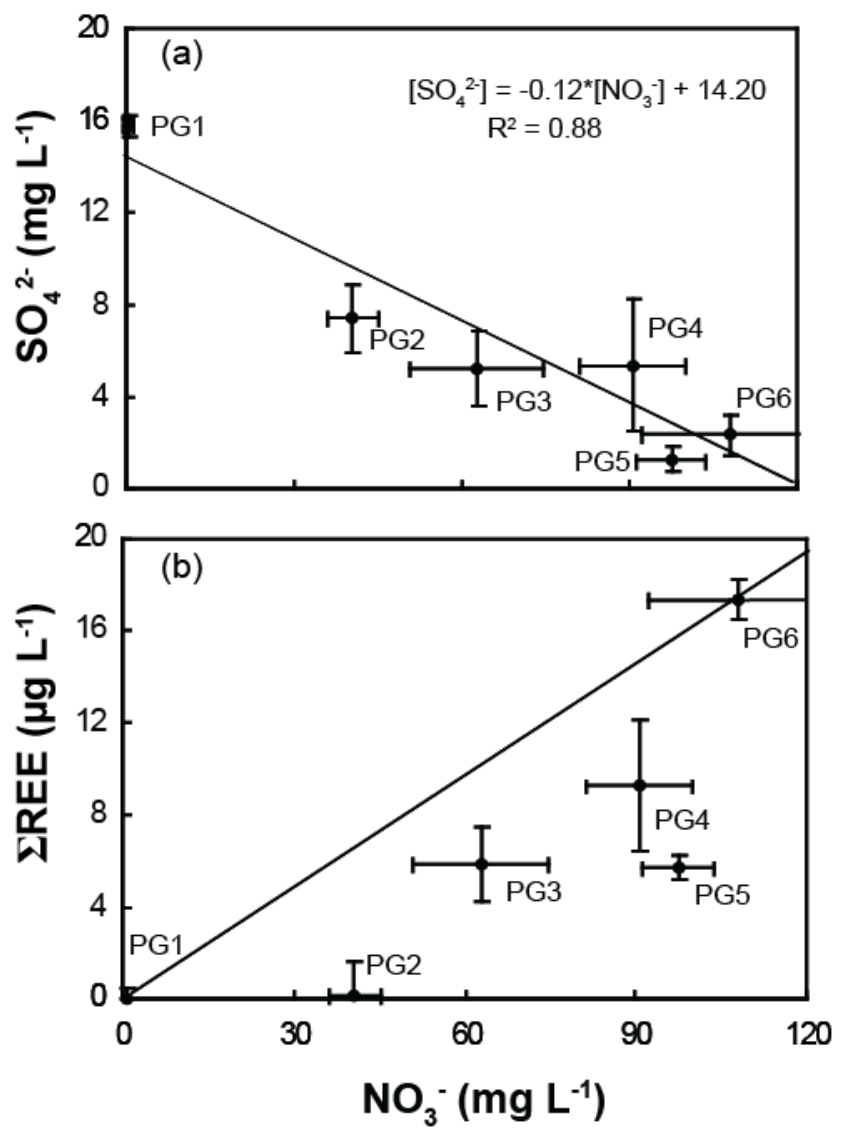

Fig.6 


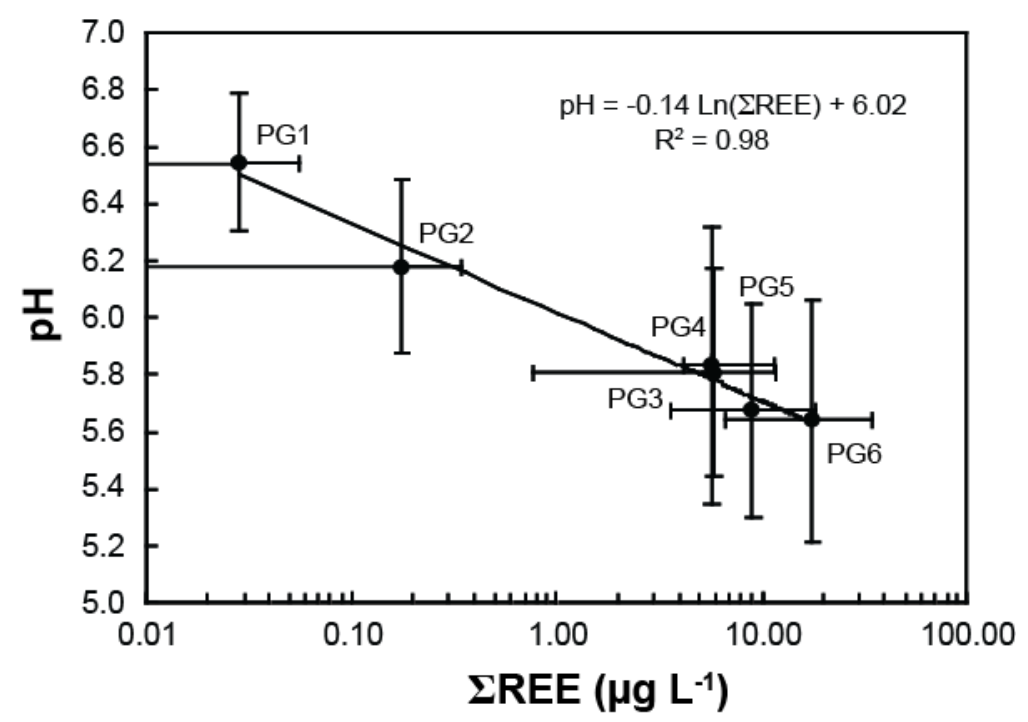

Fig.7 

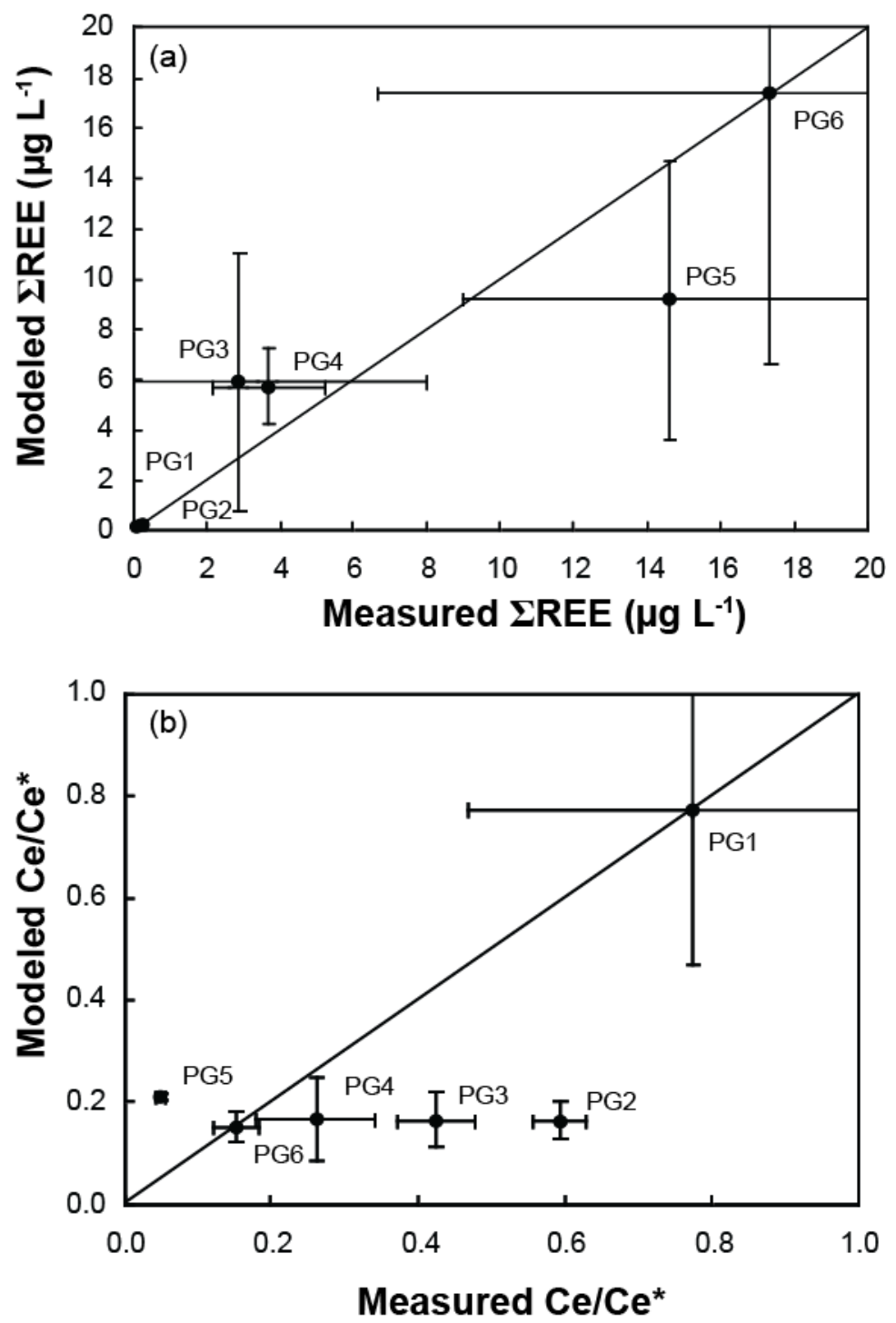

Fig.8 

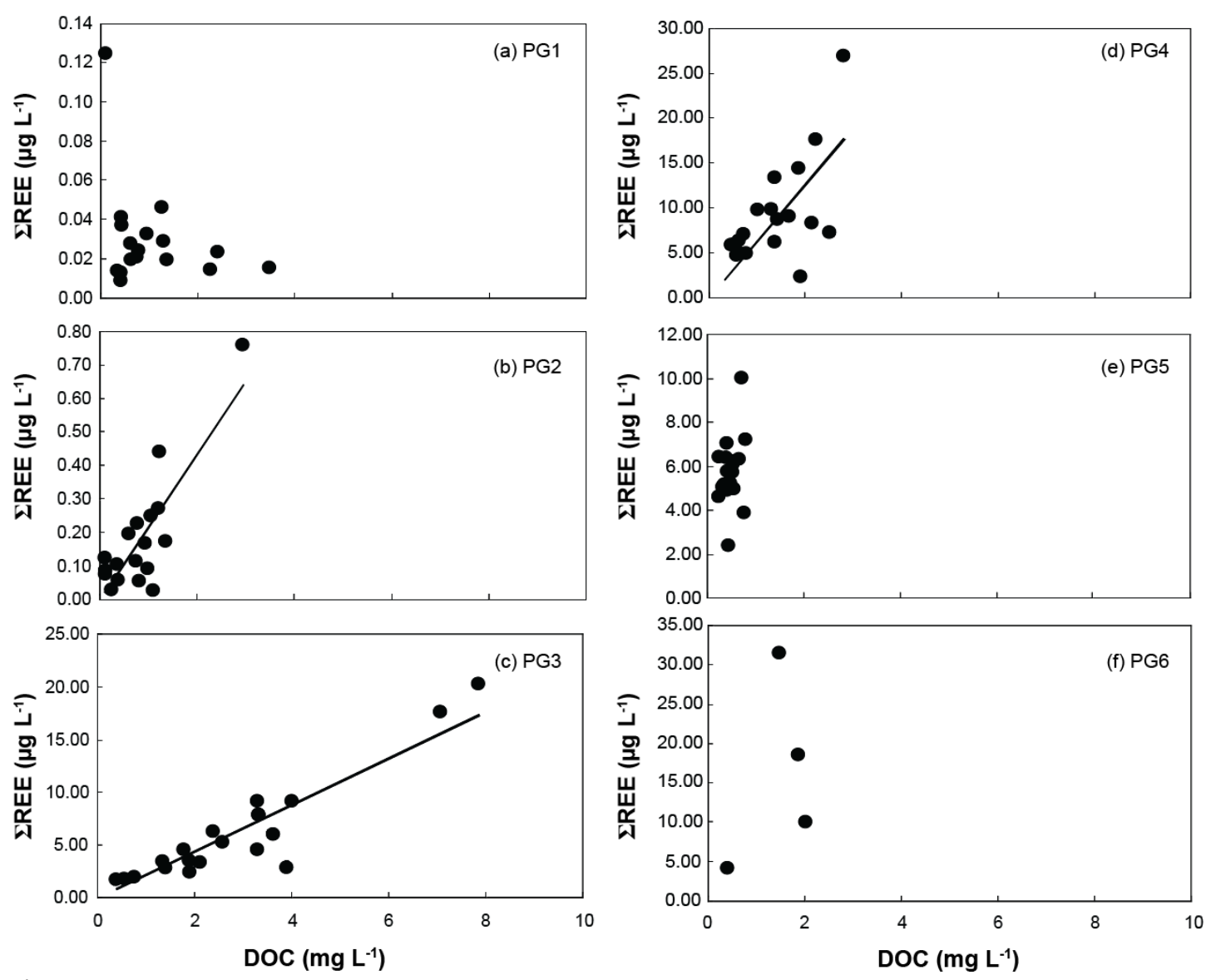

Fig.9

43 

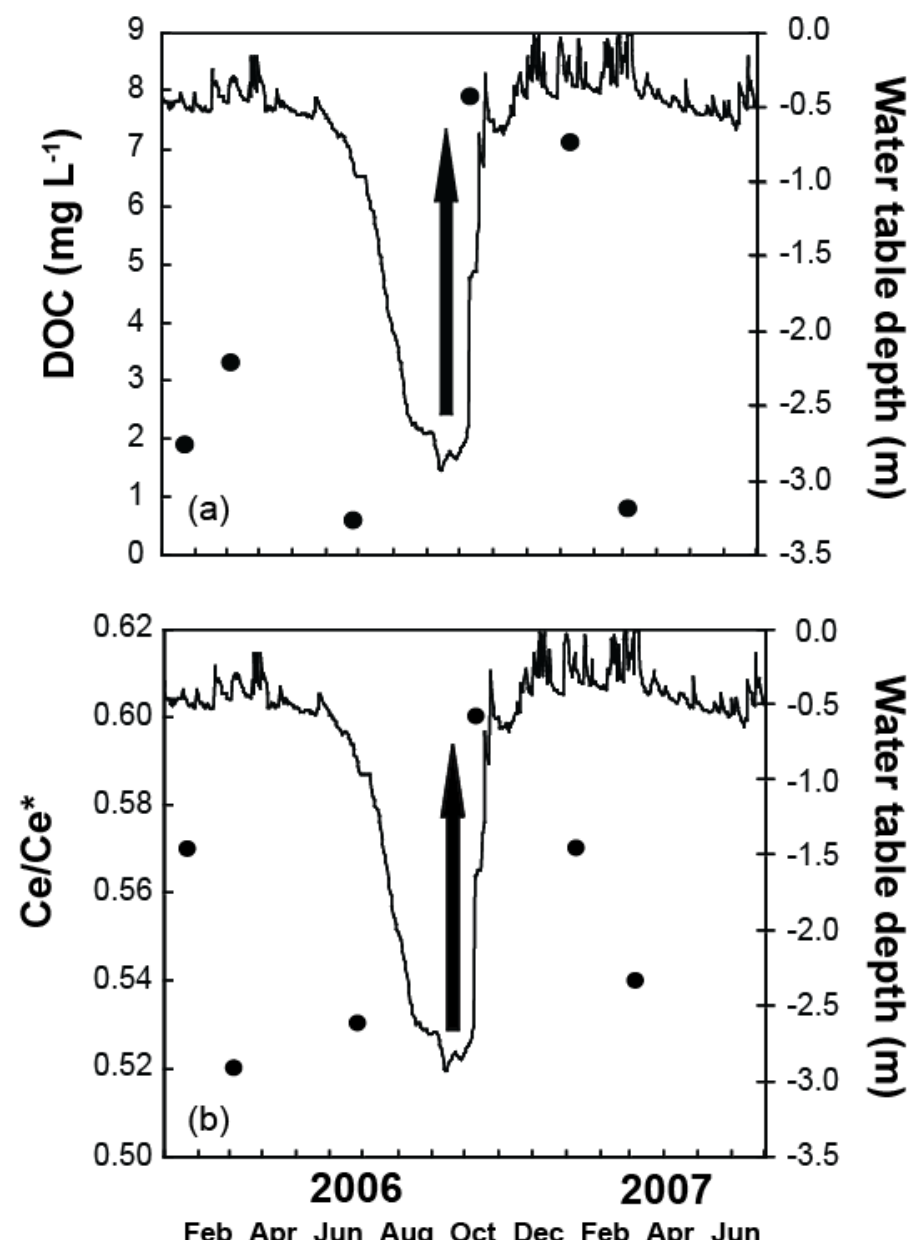

Fig.10 


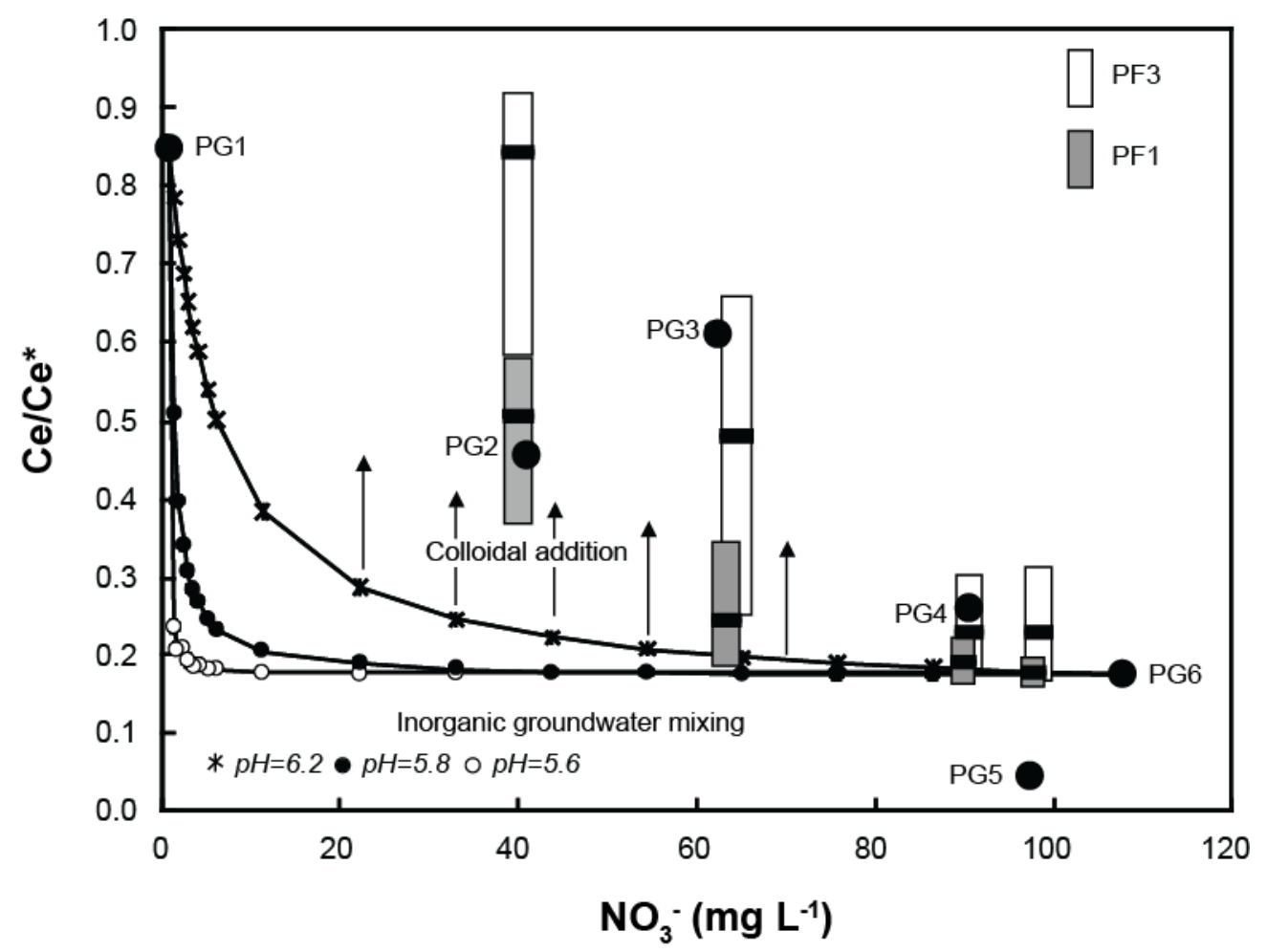

Fig.11 


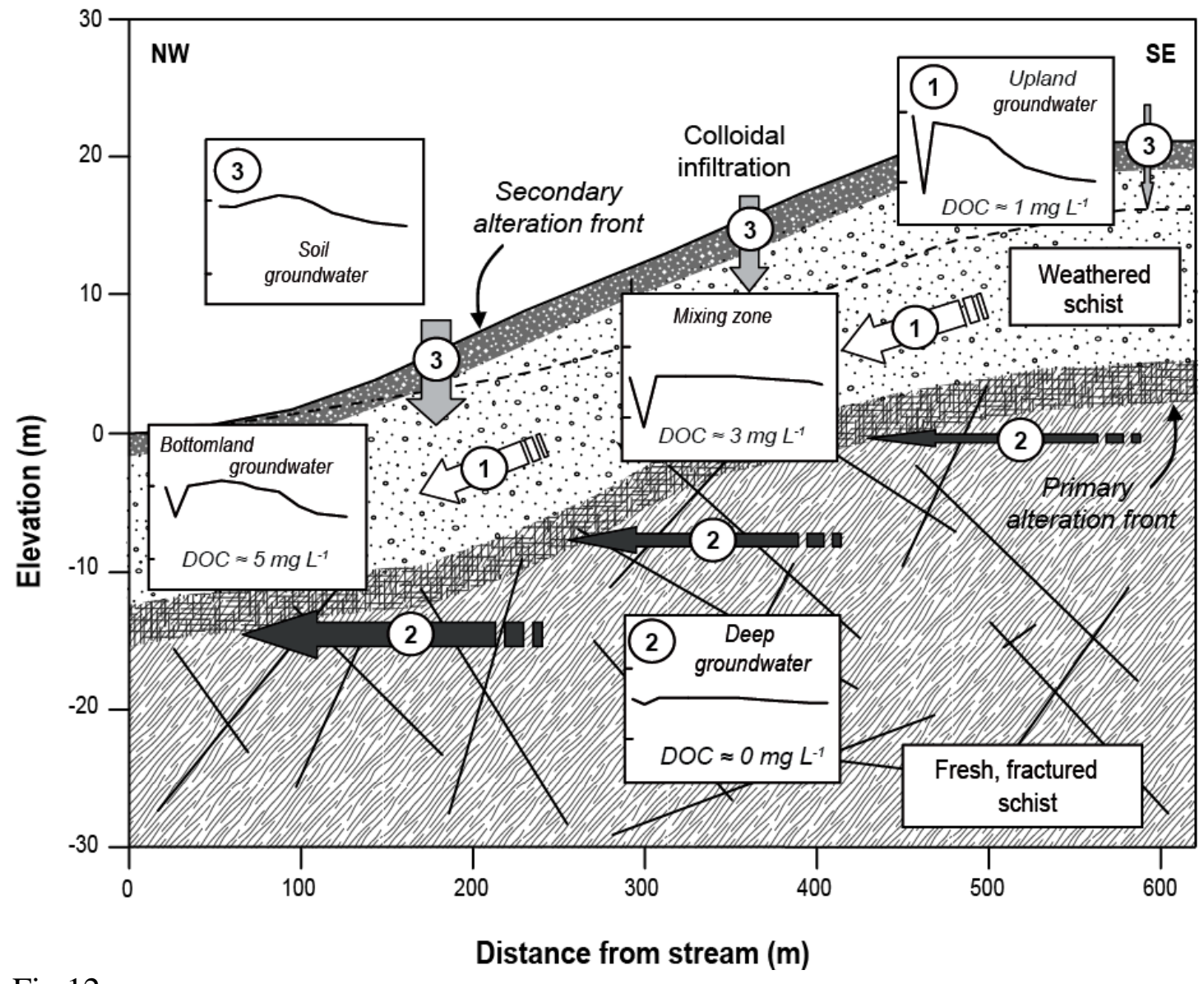

Fig.12 


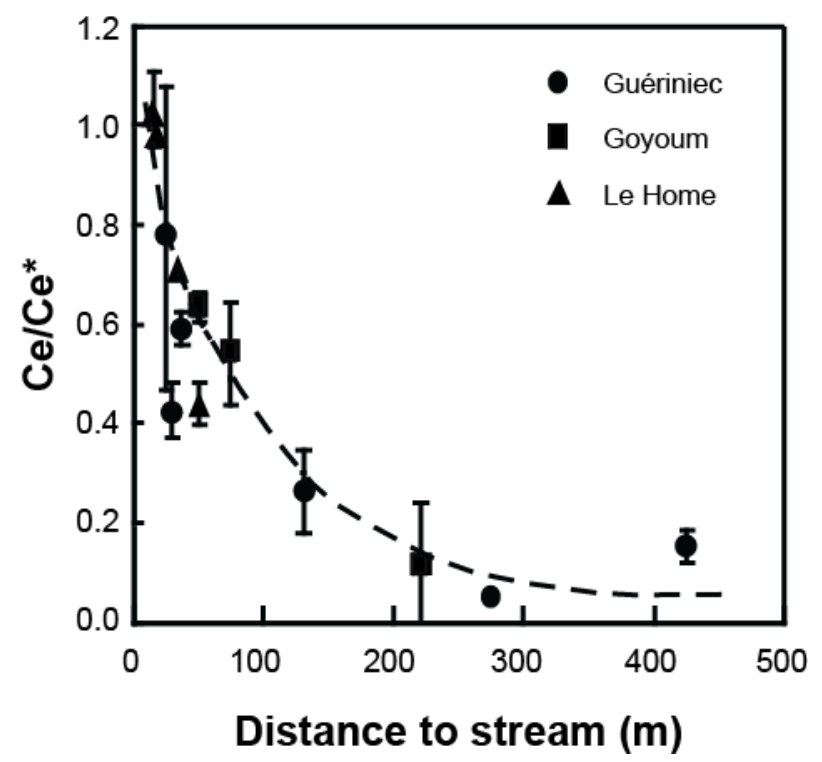

Fig.13 